OPEN ACCESS

Edited by:

Jianbo Jia

Guangzhou University, China

Reviewed by:

Xiang Wang,

University of California, Los Angeles,

United States

Isabelle R. Miousse,

University of Arkansas for Medical

Sciences, United States

*Correspondence:

Mallikarjuna Rao Gedda

gm.rao@bhu.ac.in

Piyoosh Kumar Babele

piyoosh2006@yahoo.co.in

†These authors have contributed equally to this work

Specialty section: This article was submitted to

Nanobiotechnology,

a section of the journal Frontiers in Bioengineering and

Biotechnology

Received: 02 July 2019

Accepted: 05 September 2019

Published: 20 September 2019

Citation:

Gedda MR, Babele PK, Zahra K and

Madhukar P (2019) Epigenetic

Aspects of Engineered Nanomaterials:

Is the Collateral Damage Inevitable?

Front. Bioeng. Biotechnol. 7:228.

doi: 10.3389/fbioe.2019.00228

\section{Epigenetic Aspects of Engineered Nanomaterials: Is the Collateral Damage Inevitable?}

\author{
Mallikarjuna Rao Gedda ${ }^{1 * t}$, Piyoosh Kumar Babele ${ }^{2 * t}$, Kulsoom Zahra ${ }^{3 \dagger}$ and \\ Prasoon Madhukar ${ }^{4 \dagger}$
}

${ }^{1}$ Department of Biochemistry, Institute of Science, Banaras Hindu University, Varanasi, India, ${ }^{2}$ Department of Chemical and Biomolecular Engineering, Vanderbilt University, Nashville, TN, United States, ${ }^{3}$ Department of Biochemistry, Institute of Medical Sciences, Banaras Hindu University, Varanasi, India, ${ }^{4}$ Department of Zoology, Institute of Science, Banaras Hindu University, Varanasi, India

The extensive application of engineered nanomaterial (ENM) in various fields increases the possibilities of human exposure, thus imposing a huge risk of nanotoxicity. Hence, there is an urgent need for a detailed risk assessment of these ENMs in response to their toxicological profiling, predominantly in biomedical and biosensor settings. Numerous "toxico-omics" studies have been conducted on ENMs, however, a specific "risk assessment paradigm" dealing with the epigenetic modulations in humans owing to the exposure of these modern-day toxicants has not been defined yet. This review aims to address the critical aspects that are currently preventing the formation of a suitable risk assessment approach for/against ENM exposure and pointing out those researches, which may help to develop and implement effective guidance for nano-risk assessment. Literature relating to physicochemical characterization and toxicological behavior of ENMs were analyzed, and exposure assessment strategies were explored in order to extrapolate opportunities, challenges, and criticisms in the establishment of a baseline for the risk assessment paradigm of ENMs exposure. Various challenges, such as uncertainty in the relation of the physicochemical properties and ENM toxicity, the complexity of the dose-response relationships resulting in difficulty in its extrapolation and measurement of ENM exposure levels emerged as issues in the establishment of a traditional risk assessment. Such an appropriate risk assessment approach will provide adequate estimates of ENM exposure risks and will serve as a guideline for appropriate risk communication and management strategies aiming for the protection and the safety of humans.

Keywords: nanomaterials (ENMs), nanotoxicity, epigenetic modifications, nanotheranostics, protein-corona, nano-risk assessment

\section{INTRODUCTION}

The environment surrounding us has a plethora of natural and manmade toxicants. These toxicants have gained access to almost every aspect of our life such as air, water, food, homes, workplaces, and belongings. It is very difficult to detoxify and eliminate toxicants after their entry into the human body, leading to the development of different syndromic symptoms. The exposure to these toxicants causes severe illness, diseases, and disability or death. Some of the common 
environmental toxicants are chemical compounds such as pesticides, heavy metals, plastics, and hydrocarbons. Many of these chemical compounds possess carcinogenic properties and, due to their common use in our society, are unavoidable. The jumbled chaos and rapid industrialization have profound effects on the augmentation of the air, water, and soil pollution. One of the rapidly emerging research areas in the twenty-first century is nanotechnology. Due to the advent and advancement of the nanoscience and technologies many engineered nanomaterials (ENMs) have been given access to our lives. ENMs have a broad spectrum of applications in various fields, such as in the fields of nanotheranostics and personalized medicine (the field of delivering a suitable drug to the right subjects at a precise time). The use of personalized medicine for cancer therapy is one of the promising areas in nanotheranostics (Yaari et al., 2016). Due to their widespread application, manufacture, and disposal, ENMs are released into the natural environment and so their accidental consumption is inevitable. The appearance of ENMs in the soil, water, and air could pose harmful threats for both humans and the environment, leading to serious health issues (Singh and Singh, 2019). Over recent years, it has been observed that epigenetic modifications greatly influence human physiology and development. There are innumerable pieces of evidence of epigenetic dysregulation in several human diseases, especially cancer, and much of drug discovery research is focusing on epigenetics (Strahl and Allis, 2000; Robertson, 2005; Portela and Esteller, 2010; Chervona and Costa, 2012). Therefore, the concept of personalized nanomedicine is modestly improved by epigenetic biomarkers. A large number of ENMs are being used as drug carriers in personalized medicine for drug delivery and diagnosis. These drugs significantly improve drug delivery to targeted cells as compared to the free diffusion of drug molecules. Although these drug delivery systems are advantageous over conventional chemotherapy, the substantial unidentified issues and potential cytotoxicity associated with the ENMs cannot be ignored (Oberdörster et al., 2005). The nanoscale materials have diverse properties and hence distant toxicity parameters in comparison to their larger counterparts. The destruction of cancerous cells by ENMs-based drug delivery system selectively removes the tumor. However, ENM associated non-cancerous cell dysfunctions and their repercussions can't be ignored, therefore nanomedicine and nanotoxicity have a strong correlation. The understanding of the interconnections between ENMs-based drug administration and the related toxicity greatly broadens our understanding of therapeutic strategies because ENMs share similar biological fates/responses in the body.

The toxicity caused by ENMs affects organisms ranging from prokaryotes to higher eukaryotes, including humans, and is well-documented (Singh and Singh, 2019). The exposure of ENMs has been well-studied in various in vivo and in vitro assays leading to cytotoxicity, genotoxicity, peroxidation of lipids, micronuclei formation, apoptosis, and altered expression of associated genes as shown in Figure 1. The other adverse effects of ENMs are the inflammatory response, reproductive toxicity, immunotoxicity, and non-genotoxic carcinogenicity (Dusinska et al., 2017). Recent studies utilizing modern “-omics" (proteomics and metabolomics) technologies were successful in drawing significant conclusions of underlying mechanisms of nanotoxicity (Babele, 2019; Babele et al., 2019). The majority of the nanotoxicity studies are conducted at genetic levels and some of the proposed mechanisms for toxicity are altered gene and protein expressions of major cellular pathways (Babele et al., 2018). However, epigenetic variations have gained relatively little attention. The mechanism of modulation of epigenetic processes dependent on cellular and potentially complex disease is a promising topic. The understanding of the interaction occurring at the interface between ENMs and biological components is necessary to predict the fate and concern of these injected ENMs and addressing the concerns of ENM based drug targeting. To illustrate a classical mechanism that maintains the epigenetic state, a little information about epigenetic modification is must and our review provides a detailed account of the fundamental principles and concepts.

\section{MECHANISM OF ENMS INTERNALIZATION}

Understanding of the underlying mechanism(s) involved in cellular uptake and intracellular trafficking of ENMs is essential for evaluating the biomedical function, bio-distribution, toxicity, and therapeutic efficacy (Behzadi et al., 2017; Foroozandeh and Aziz, 2018). The various factors that affect the uptake of ENMs have been extensively covered in the following section and illustrated in Figure 2. The insight into the role of physicochemical parameters such as size, shape, charge, hydrophobicity/hydrophilicity, and surface functionalization on internalization is essential as these properties directly alter the uptake level, mode of endocytosis, and cytotoxicity of ENMs. The membrane permeability and integrity rely largely on the size and surface chemistry of interacting ENMs, and a particular type may utilize multiple endocytic pathways depending on its size. ENMs with sizes ranging from few to several hundred nanometers internalize via pinocytosis/macropinocytosis, and those with sizes ranging from $250 \mathrm{~nm}$ to $3 \mu \mathrm{m}$ undergo phagocytosis, while ENMs in the size range of $120-150 \mathrm{~nm}$ and even $200 \mathrm{~nm}$ internalize through clathrin- or caveolin-mediated endocytosis. Larger ENMs internalize with great difficulty via caveolaemediated pathway due to hindrance caused by the size of caveolae (Lu et al., 2009). The optimum size at which a particular ENM shows most efficient internalization with a higher uptake rate is $50 \mathrm{~nm}$, while the uptake is reduced with sizes larger or smaller than this; although the clearance rate of larger ENMs is much faster than that of smaller ones (Osaki et al., 2004; Geiser et al., 2005; Chithrani and Chan, 2007; Jin et al., 2009; Lu et al., 2009; Wang et al., 2010).

The shape of ENMs is another crucial factor in its cellular uptake. Several experiments have shown that rod-shaped ENMs undergo lower cellular uptake than spherical ENMs (Chithrani et al., 2006; Chithrani and Chan, 2007). On the contrary, Gratton et al., while working on monodisperse hydrogel particles, demonstrated that rod-shaped ENMs have the highest internalization rates in HeLa cells compared to spheres, cylinders and cubes (Gratton et al., 2008). In a recent study on rodshaped polystyrene NPs on Caco- 2 cells, two-fold greater uptake 


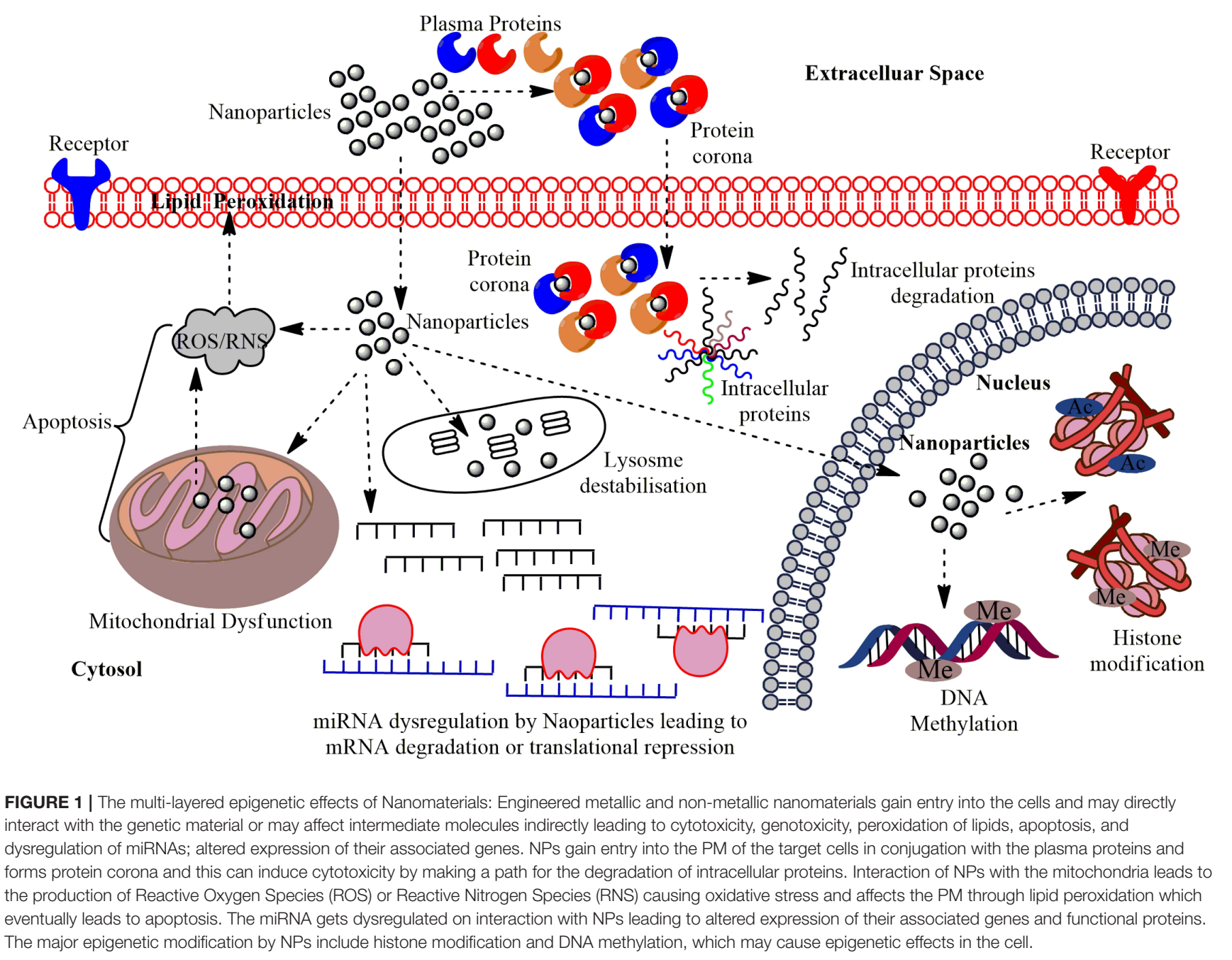

of rod and disc-shaped NPs was reported (Banerjee et al., 2016). A study by Herd et al. revealed that spherical NPs undergo clathrin-mediated endocytosis while their worm-like counterparts internalize via micropinocytosis or phagocytosis due to their large sizes (Herd et al., 2013).

The charge on the surface of ENM is a crucial factor influencing its cellular uptake and recently, several attempts are being made to engineer the surface charge of NP rendering it cationic or anionic ( $\mathrm{Zhu}$ et al., 2012). The negative charge on the plasma membrane enhances the uptake of positively charged ENMs. Many studies demonstrated that positively charged ENMs have higher uptake rates and are internalized via macropinocytosis than negatively charged ENMs which prefer clathrin-/caveolae-independent endocytosis (Dausend et al., 2008; Marano et al., 2011; Panariti et al., 2012). The uptake of positively charged ENM is believed to increase the fluidity of the cell membrane while negatively charged ENM causes gelation of the membrane and has higher uptake rate than the neutral ones (Wang et al., 2008; Arvizo et al., 2010). Charged ENMs show better adhesion to the membrane bilayer than the uncharged.
The ENMs with hydrophobicity show highest thermodynamic stability in the middle of the lipid bilayer while the hydrophilic particles get lodged on the surface, which has been observed in both AuNPs (Lee et al., 2013) and quantum dots (Olubummo et al., 2012). Surface modification and elasticity also play a critical role in cellular uptake. Stiffer ENMs internalize more rapidly and efficiently as compared to the softer ones (Anselmo et al., 2015). Gold, QDs, and magnetic ENMs are hard with higher elastic values, while biodegradable polymers, liposomes, and hydrogels are soft ENMs with lower elastic values. Surface modifications by functionalizing ENMs with PEG (polyethylene glycol), negatively charged groups like carboxyl $(-\mathrm{COOH})$, positively charged amino $\left(-\mathrm{NH}_{2}\right)$ group and neutral hydroxyl $(-\mathrm{OH})$ groups help in reducing toxicity, enhancing stability and improving cellular internalization (Chompoosor et al., 2010). The enhancement of positive surface charge enhances the cellular uptake of ENMs (Holzapfel et al., 2006; Alexis et al., 2008). Likewise, $\mathrm{COOH}$ functional groups increase the negative charge of ENMs and boost its uptake (Holzapfel et al., 2006). 


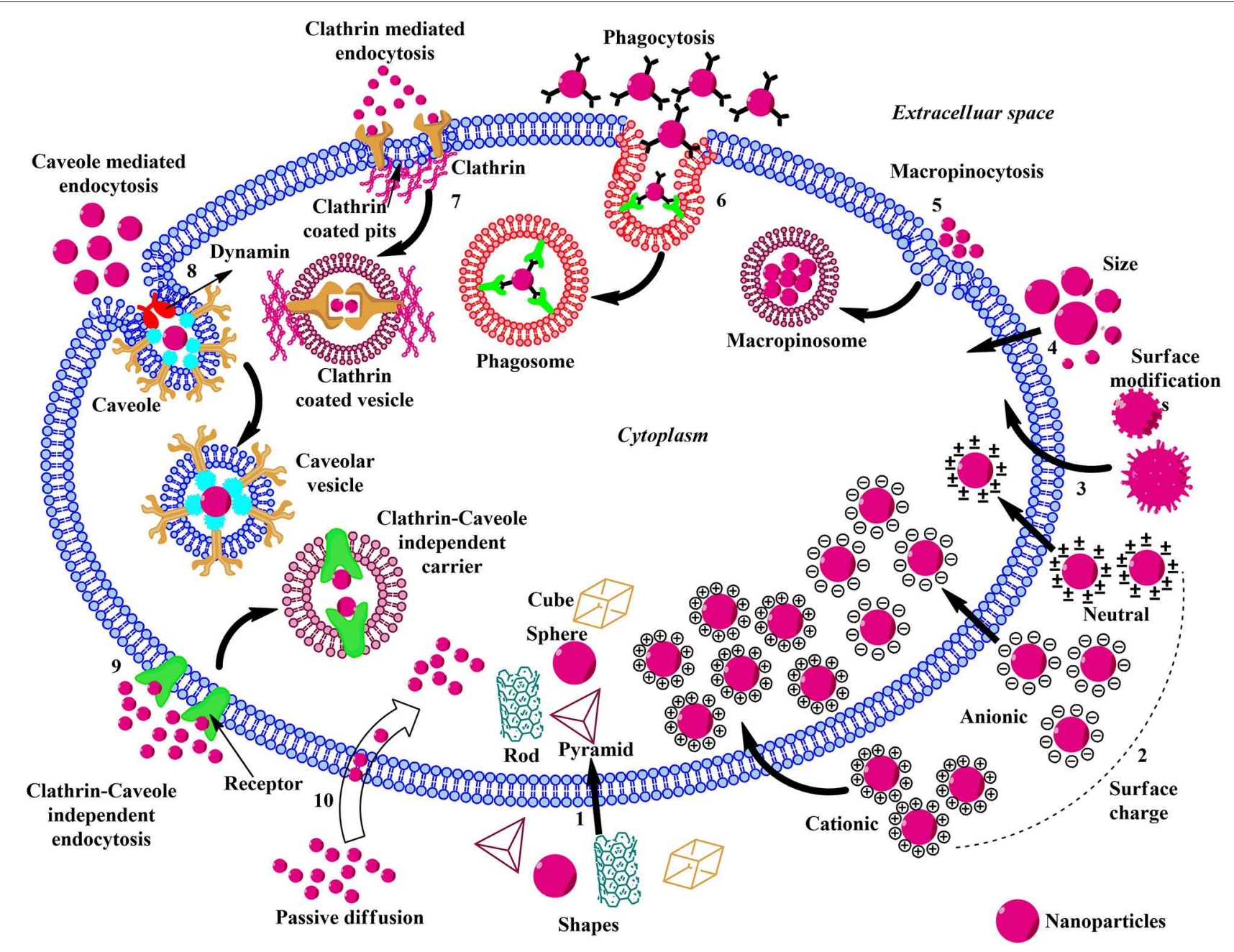

FIGURE 2 | Schematic illustration of the influence of physicochemical properties, endocytic, and non-endocytic pathways on the cellular uptake of ENMs. (1) The shape of the ENMs play pivotal role in the uptake and there are considerable amounts of variations in the translocation rate of rod, cube, pyramid, and sphere-shaped ENMs. (2) Charged ENMs show better uptake than the uncharged. The positively charged ENMs internalize via macropinocytosis and negatively charged NPs enter via clathrin/caveolae independent endocytosis. (3) ENMs in the size range of 30-50 nm interact efficiently with the receptors on the plasma membrane and show rapid uptake via receptor-mediated endocytosis. (4) Surface modification of ENMs involve coating their surface with $\mathrm{PEG}$, cationic $\left(-\mathrm{NH} \mathrm{H}_{2}\right)$, anionic $(-\mathrm{COOH})$, or neutral $(-\mathrm{OH})$ molecules to enhance uptake and reduce toxicity. (5) Macropinocytosis; upon recognition, the ENMs and surrounding extracellular fluid are entrapped in large vesicles (macropinosome) formed by the back fusion of large membranous extensions. (6) Phagocytosis; Antibodies or complement proteins (opsonins) get adsorbed on the surface of ENM and the opsonized particles are recognized through receptors present on phagocytic cells and get internalized. (7) Clathrin-mediated Endocytosis; The ENM binds with the surface receptor present within the clathrin-coated pits inducing invagination and the vesicle is released into the cytoplasm by the help of scission protein; dynamin. (8) Caveolae-mediated Endocytosis; Caveolin proteins form a flask-like curvature with the trapped ENM and the resulting vesicle is released into the cytoplasm by dynamin. (9) Clathrin/Caveole independent Endocytosis- takes place in the cells lacking clathrin or caveolae and it is a non-destructive uptake mechanism which bypasses the lysosomal hydrolysis. (10) Passive Diffusion- is a non-endocytic uptake mechanism, mainly utilized by the DPA-QDs.

\section{Cellular Uptake Pathways of ENMs}

ENMs are mostly small, polar molecules that utilize the endocytic pathway to infiltrate into the cells, which can be categorized into phagocytosis and pinocytosis. The pinocytic mode can be sub-categorized into caveolae-mediated, clathrin-mediated, clathrin- and caveolae-independent endocytosis and macropinocytosis (Behzadi et al., 2017; Foroozandeh and Aziz, 2018). All types of endocytic and non-endocytic pathways for ENMs internalization are summarized below.

\section{Phagocytosis}

Larger ENMs such as polystyrene, radiolabeled albumin, polymer-lipid hybrid nanoparticle (PLN), PEGylated gold nanorods, and nanospheres, ranging in a size of $200-2,100 \mathrm{~nm}$ are efficiently uptaken by phagocytes by adsorption of opsonins such as immunoglobulin, laminin, fibronectin, or complement proteins to the surface of ENMs (Caviston and Holzbaur, 2006; Hillaireau and Couvreur, 2009; Xiang et al., 2012; Pauwels et al., 2017). Opsonized ENMs are easily recognized by phagocytes via specific ligand-receptor interaction. The receptors present 
on the surface of phagocytes are complement receptors, Fc receptors, mannose/fructose receptors, and scavenger receptors. The opsonized ENM-phagocyte complex initiates a signaling cascade leading to actin polymerization, formation of cell surface extensions, engulfing, internalization, and formation of phagosome. ENMs with different charges attract opsonins leading to enhanced phagocytosis in comparison with the uncharged ones.

\section{Clathrin-Mediated Endocytosis}

Poly (lactic-co-glycolic acid), D, L-polylactide, poly(ethylene glycol-co-lactide), Silica-based $\left(\mathrm{SiO}_{2}\right), \quad$ Herceptin-coated gold, Carbon Nanotubes (CNTs), Silica Nanotubes (SNTs), polystyrene, carboxylated polystyrene, alginate-chitosan, carboxylated quantum dots, and almost all lipid-based ENMs internalize via Clathrin-mediated endocytosis (Behzadi et al., 2017; Foroozandeh and Aziz, 2018). This process involves the binding of ligand in the extracellular fluid to the low-density lipoprotein receptor on the cell membrane forming ligandreceptor complex which migrates to that region of the cell membrane, which is rich in clathrin $(0.5-2 \%$ of the cell surface) and gets engulfed through the formation of clathrin-coated vesicles (Conner and Schmid, 2003; Doherty and McMahon, 2009; Capraro et al., 2013; Vanlandingham et al., 2014; Lu R. et al., 2016; Ferguson et al., 2017; Hassinger et al., 2017). On internalization, the clathrin coat is removed followed by fusion of the cargo with endosomes and finally with lysosomes.

\section{Caveolae-Mediated Endocytosis}

Amine labeled polystyrene $(60 \mathrm{~nm})$, alginate-chitosan $(157 \mathrm{~nm})$, silica $60 \mathrm{~nm})$, and polystyrene NP $(40 \mathrm{~nm})$ utilize this mode of internalization (Behzadi et al., 2017; Foroozandeh and Aziz, 2018). Caveolae (flask-shaped membranous invaginations ranging from 50 to $80 \mathrm{~nm}$ ) composed of membrane protein caveolin-1 are distributed in the regions of dense bodies anchoring the cytoskeleton in epithelial cells, endothelial cells, fibroblast cells, adipocytes, and smooth muscle cells (Thorn et al., 2003; Parton and Simons, 2007; Wang et al., 2011). After detaching from the plasma membrane, caveolae fuse with cellular compartment called caveosomes, which exist at neutral $\mathrm{pH}$ and are able to bypass the lysosome preventing the hydrolytic degradation and thus useful for the internalization of ENMs.

\section{Clathrin/Caveolae Independent Endocytosis}

Clathrin/caveolae independent endocytosis is mainly shown by folate functionalized ENMs (Foroozandeh and Aziz, 2018). The binding of folate-modified ENM to its receptor leads to its non-destructive delivery into the cytoplasm. These cargos often remain in endocytic compartments bypassing the lysosome. The clathrin/caveolae independent endocytosis occurs in cells lacking clathrin and caveolae and is mostly used by growth hormone, Interleukin-2 and glycosylphosphatidylinositol linked proteins to internalize (Damm et al., 2005; Kirkham et al., 2005; Soldati and Schliwa, 2006; Mellman and Nelson, 2008; Sandvig et al., 2011; Ferreira and Boucrot, 2018; Zhang F. et al., 2018).

\section{Macropinocytosis-}

Micron-sized ENMs like polystyrene $(40 \mathrm{~nm})$, carboxylated polystyrene (40 and $200 \mathrm{~nm}$ ) and lipid ENMs $(60 \mathrm{~nm})$ are translocated through this mode (Behzadi et al., 2017). The rearrangement of the cytoskeleton led to the formation of large membranous extensions or ruffles which forms large vesicles on fusion with the cell membrane, trapping a large amount of extracellular fluid containing ENMs and dissolved molecules, which are then transported to endocytic vesicles (Lim and Gleeson, 2011). Except for brain microvessel endothelial cells, almost all cells show macropinocytosis (Kuhn et al., 2014).

\section{ENMS AND BIOLOGICAL INTERACTIONS \\ The ENMs-Protein Corona Complex}

After systematic internalization into the biological tissues, ENMs are exposed to various biological fluids and form a dynamic ENM-protein corona complex. This complex exemplifies the "real identity" of ENMs in a biological entity, thus this interaction should be carefully examined to envisage and control the fate of ENMs, including systemic circulation, biodistribution, and bioavailability and clearance (Tenzer et al., 2013; Liu et al., 2015). Upon exposure with the active bio-molecules within the cells/tissues, a "crown" or corona is formed around the ENMs, transforming these ENMs with a biological component i.e., corona (PC) as shown in Figure 3. Although, PC is primarily composed of proteins, and the involvement of other bio-molecules i.e., nucleic acids, sugars, and lipids are not yet documented. The physicochemical properties of ENMs are greatly altered by the adsorption of proteins on ENMs, and ENMPC complex formation alters the size, surface charge, surface composition, and functional groups of ENMs, thus giving them a new biological identity (Tenzer et al., 2013; Liu et al., 2015). A variety of cellular responses including cellular uptake, fibrillation, circulation time, bioavailability, and even toxicity are determined by the ENM-PC complex, not by the bare ENMs. Therefore, a proper understanding of the interaction between ENM-PC complex and cellular processes is fundamentally important for the identification of a potential model of nanotoxicity. It is quite evident that different corona profiles are produced by different characteristics of ENMs. The ENM-PC complexes can control cellular behavior, bioavailability, and biological responses, and possess many unique physicochemical and biological characteristics. ENMs are excellent carriers for targeted drug delivery because of their specific structural properties, large surface/volume ratio, the capability to append specific agents on their respective surface, the potentiality to cross cellular and tissue barriers, in addition to their long circulation time in the blood. These features significantly contribute to the protein corona formation and is an unavoidable phenomenon. Generally, the protein corona forms around the hydrophobic ENMs because these materials present a greater surface area for protein adsorption and may cause agglomeration and higher opsonization leading to shorter systemic circulation time in blood than the hydrophilic ENMs. The hydrophilic ENMs although, with a lower capacity of protein adsorption, can bind proteins when exposed to the cellular media. The adsorption 
of proteins on the surface of ENMs and their biological responses are decided by many factors, such as the presence of functional groups and other distinct mechanical properties. In an experiment testing the IgG adsorption behavior and phagocytic efficiency of emulsion droplets and solid polystyrene NPs, it was seen that IgG gets homogeneously distributed around the polystyrene beads independent of its density. In case of its low densities, IgG was concentrated in the interface between the emulsion droplets and the cell, while at higher densities, IgG clusters were seldom visible. This is a clear indication that the emulsion droplets allowed the adsorbed proteins to diffuse and relocate at the interface. Hence, even low quantities of protein can do the job by using the emulsion formulations, while achieving the same effect.

\section{ENMs and Their Structure-Activity Relationships}

Structure-Activity Relationship (SAR) is the correlation between the physicochemical characteristics of ENMs with their biological activities. This allows the prediction and modification of the activity of ENM by manipulation of the molecular structure. The functional or chemical groups responsible for evoking the biological effect can be determined through the analysis of SAR. The SAR approach can also be used to model the potential hazards of ENMs and predict the potential risks specific to ENMs based on specific structural and compositional features (Oksel et al., 2015). The major physicochemical properties that are assessed for their contribution to the bio-effects include length, diameter, thickness, surface reactivity, aspect ratio, zeta potential, biotransformation, hydrodynamic size, surface area, and ability to catalyze ROS generation. A combinatorial $\mathrm{Fe}_{2} \mathrm{O}_{3}$ library with precisely controlled size and shape revealed that cell migration is determined by surface reactivity; inflammatory effects of $\mathrm{Fe}_{2} \mathrm{O}_{3}$ nanorods and nanoplates are controlled by particle properties, metabolite, and protein changes, AR and surface reactivity (Cai et al., 2018). Engineered carbonaceous nanomaterials (ECNs) like SWCNTs, MWCNTs, graphene, and graphene oxides possess high conductivity, tensile strength, surface area, flexibility as well as hydrophilicity and dispersibility in aqueous solutions. It was observed that surface charge, aspect ratio, dispersion state, and surface reactivity are the major contributors of CNTinduced lysosomal damage, cathepsin B release and NLRP3 inflammasome activation in macrophages leading to acute or chronic lung damage (Wang et al., 2017).

\section{TYPES OF EPIGENETIC MODIFICATIONS}

Epigenetic modifications are stable and heritable alterations mainly driven by three tightly regulated and interconnected processes: (i) DNA methylation, (ii) modification of histones, and (iii) regulation of non-coding RNAs (ncRNAs) that alter DNA accessibility and chromatin structure, thereby modulating the gene expression pattern (Figure 4). These processes are extensively studied and reviewed elsewhere (Strahl and Allis,
2000; Robertson, 2005; Portela and Esteller, 2010; Chervona and Costa, 2012).

In the process of DNA methylation, the covalent linking of a methyl group at the $\mathrm{C} 5$ position of cytosine residues in $\mathrm{CpG}$ dinucleotide sequences is one of the principal epigenetic tags found in the DNA and it leads to transcriptional silencing of the repeat elements, transposons, and other genes by blocking DNA recognition and binding by certain transcription factors. It has also been observed that factors like methyl CpG binding protein 2 (MeCP2) bind to the methylated DNA to repress the transcription (Hendrich and Bird, 1998) by recruiting histonemodifying enzymes such as histone deacetylases (HDAC), which promotes chromatin condensation (Robertson, 2005). The enzymes involved in the de novo methylation and maintenance of the DNA are a family of DNA Methyl Transferases (DNMTs) of which DNMT1 is predominantly responsible for maintaining $\mathrm{CpG}$ methylation by adding methyl groups to the non-methylated daughter strand formed during replication, while enzymes like DNMT3a and DNMT3b are required during embryogenesis for methylation (Cirio et al., 2008). The process of demethylation is more complex and can be passive or active. Ten-eleven translocation 2 (TET) family proteins are able to oxidize the methylated DNA into respective carboxycytosine, formylcytosine, and 5-hydroxymethylcytosine (Robertson, 2005).

The four canonical histones; $\mathrm{H} 2 \mathrm{~A}, \mathrm{H} 2 \mathrm{~B}, \mathrm{H} 3$, and $\mathrm{H} 4$ make up the nucleosomes and $\mathrm{H} 1$ as a linker, and these histones form the foundation of chromatin. Initially, histones were considered as a static scaffold for DNA packaging but recent findings reveal that they affect the chromatin condensation and DNA accessibility, by tightly regulated post-translational modifications (PTMs). PTMs can guide the state of chromatin (i.e., active vs. inactive) and eventually the expression of genes (Strahl and Allis, 2000). Histones are modified post-translationally by acetylation, methylation, and phosphorylation of tail regions and are extensively studied the phenomenon of PTMs. However, histones may also be modified in other processes, such as citrullination, ubiquitination, ADP-ribosylation, deamination, formylation, O-GlcNAcylation, propionylation, butyrylation, crotonylation, and proline isomerization (Esteller, 2008). Increment in acetylation of histone tails is usually associated with transcriptional activation of genes, while the functional consequences of methylation depend on the number of methyl groups, the residue itself, and its location within the histone tail. The addition or removal of post-translational modifications from histone tails is fairly dynamic and is achieved by a number of different histone modifying enzymes. The enzymes involved in so-called "writing" and "erasing" these reversible marks include, histone acetyltransferases (HATs), histone deacetylases (HDACs), histone methyltransferases (HMTs), histone demethylases (HDMs), histone ubiquitinating enzymes as well as deubiquitinating enzymes, and can either be specific (i.e., histone methyltransferases and demethylases) or general (i.e., HATs and HDACs) in their ability to recognize and alter the amino acid residues of histone tails (Chervona and Costa, 2012).

The third type of epigenetic regulation is mediated by ncRNA, identified relatively recently and is an emerging 


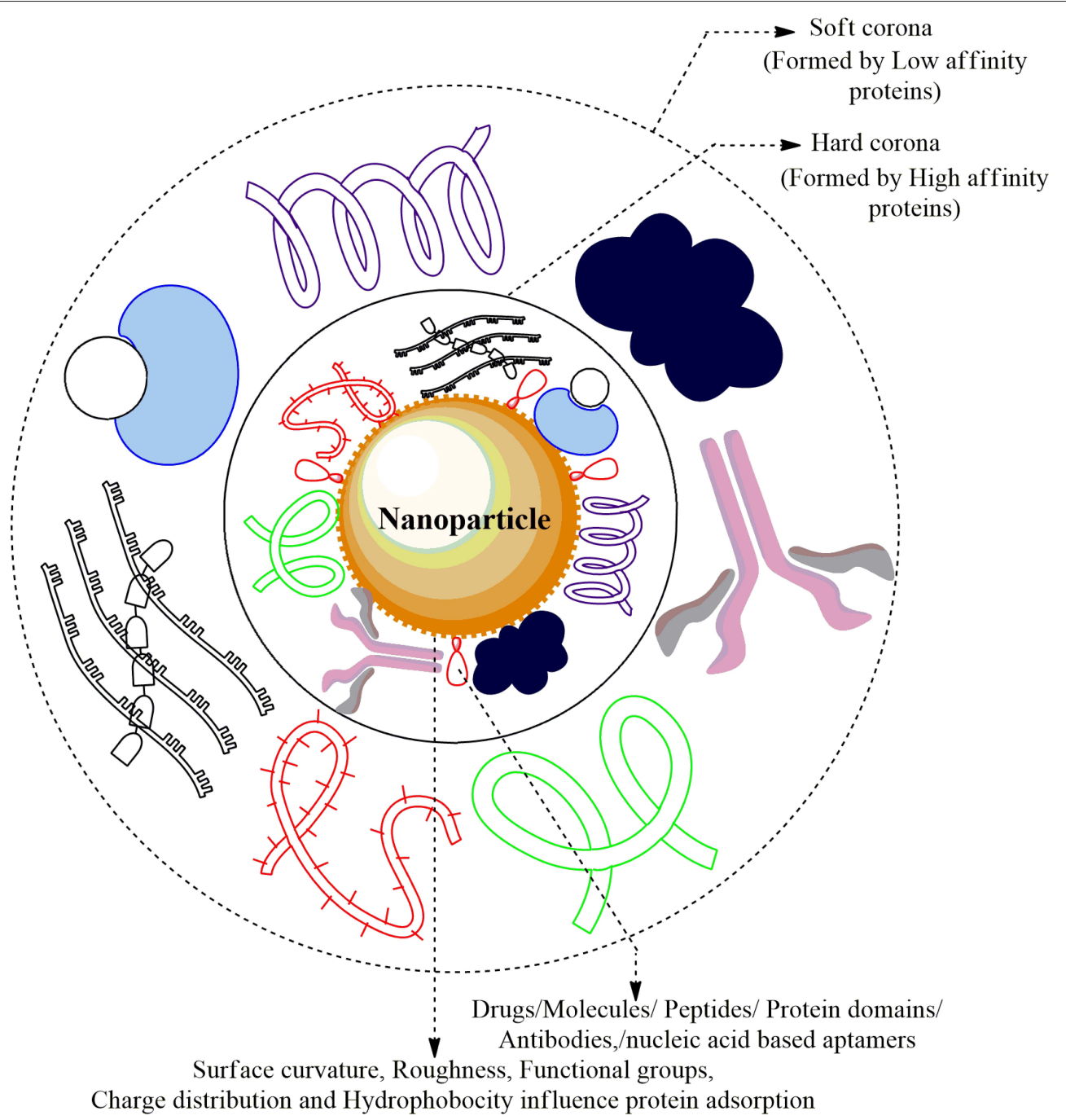

FIGURE 3 | Nanoparticle-Protein Corona (NP-PC) Complex: The cellular proteins in the plasma are adsorbed and form a sheath around the surface of ENMs forming Protein Corona. The proteins that are first to cluster around the NP are higher in abundance/mobility/affinity and form the Hard Corona while the low affinity/mobility proteins form Soft Corona over time. The Plasma proteins forming a coat around the corona are albumin, alpha-2 macroglobulin, immunoglobulin G1, apolipoprotein A-1 drugs, and several small molecules.

research field. An ncRNA is a functional RNA molecule that is transcribed from DNA but not translated into proteins. Those ncRNAs that appear to be involved in epigenetic processes can be divided into two main groups; the short ncRNAs ( $<30$ nucleotides) and the long ncRNAs ( $>200$ nucleotides). The three major classes of short non-coding RNAs are microRNAs (miRNAs), short interfering RNAs (siRNAs), and piwi-interacting RNAs (piRNAs). Generally, ncRNAs function to regulate gene expression at the transcriptional and posttranscriptional level by inducing heterochromatin formation, histone modification, DNA methylation targeting, and gene silencing (Ohnishi et al., 2010). siRNAs and miRNAs target gene promoters and direct transcriptional gene silencing by recruiting specific proteins and epigenetic remodeling complexes that suppress gene expression by promoting histone methylation
(H3K9 and H3K27), DNA methylation and histone deacetylation (Kim et al., 2006). It has also been reported that long-non coding RNAs play a pivotal role in suppressing transcription by recruiting RNA-binding proteins that interfere with histone deacetylation (Nagano and Fraser, 2009).

\section{EPIGENETIC EFFECTS OF ENGINEERED NANOMATERIALS}

Nanomaterials can induce epigenetic changes at DNA, RNA and protein levels. The epigenetics of gene expression patterns can be regulated through covalent modification of DNA, histones, small non-coding RNAs (miRNAs, siRNAs, piRNAs) and long non-coding RNAs (lncRNAs). The persistence of these 


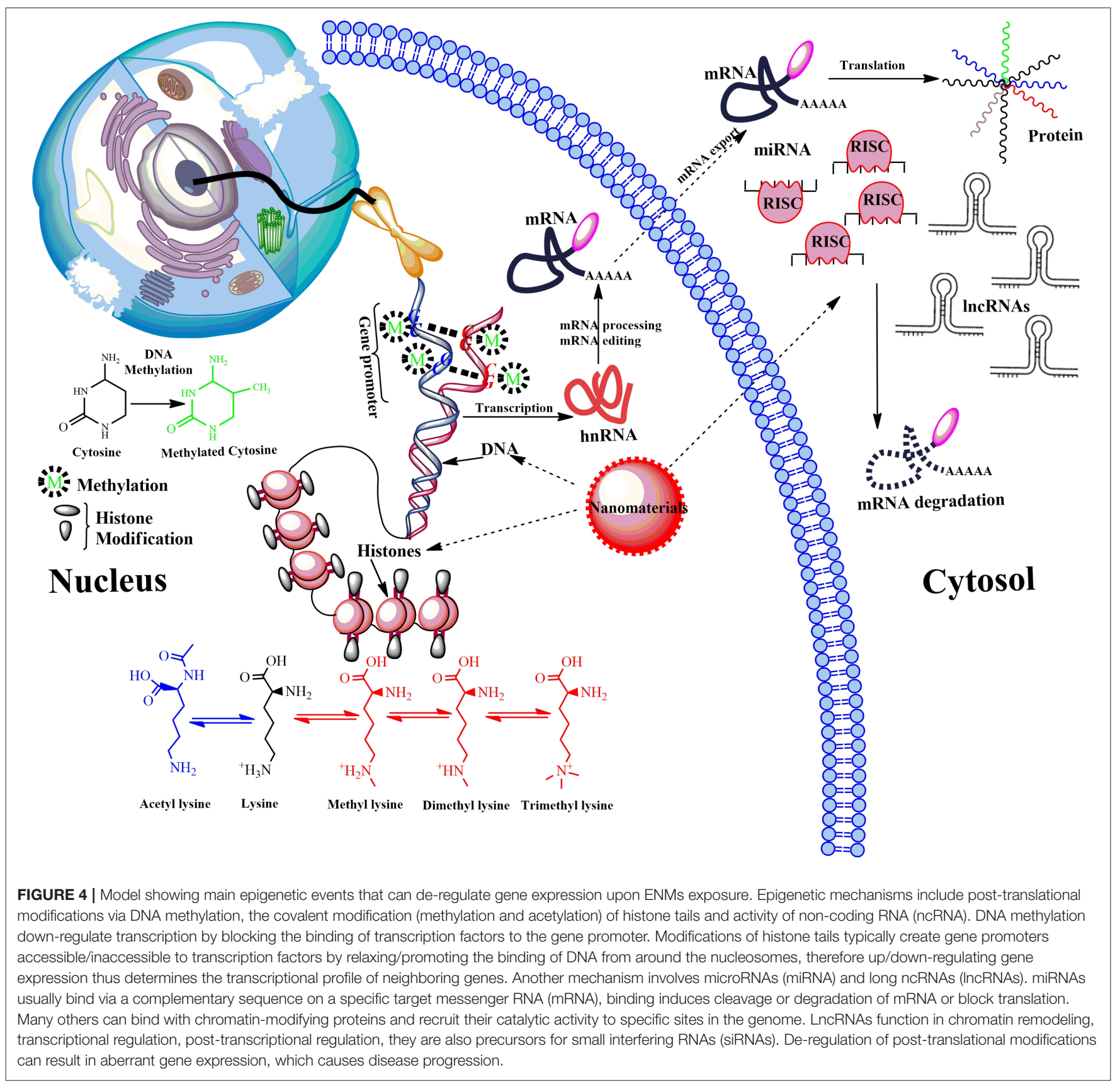

changes through the process of cell division would ensure the alteration of heritable gene expression pattern (Tabish et al., 2017). The normal growth and cellular functions are dependent upon the epigenetic control of gene expression programs. The different epigenetic modulations are shown in Figure 4 are in intercommunication within and between different regulatory mechanisms rather than working independently. The alteration in the DNA methylation of the global or gene-specific sites in the nucleus shows a profound impact on the remodeling of chromatin and their respective locus-specific expression of genes. The testing of epigenetic toxicity potential of ENMs or heavy metals acting as epimutagens has revealed that their exposure can have promising effects on the epigenome yet its contribution in disease development is unclear (Stoccoro et al., 2013). Some of the recent findings have raised agitation regarding the possible epigenetic toxicity and health effects induced by ENMs (Mytych et al., 2017; Smolkova et al., 2017). There are several such in vivo and in vitro studies which report about the alterations caused by ENMs and studies on histone modifications and expression of miRNAs further enhance our understanding of ENM-induced epigenetic changes. Significant epigenetic effects have been observed based on physical properties i.e., shape and size of ENMs affecting both at the sub-cytotoxic and subgenotoxic ENM concentrations (Smolkova et al., 2017). The 
expression of genes and proteins can be grossly affected by these epigenetic changes leading to serious health implications. The epigenetic effects of different ENMs commonly used in disease diagnosis and drug delivery are summarized below.

\section{ENMs Mediated DNA Modifications}

Methylation of DNA (other than histone methylation) is a wellstudied epigenetic signaling tool that cells use to lock the genes in the silenced state. Researchers have learned a great deal about DNA methylation, including how and where it occurs. It has also been discovered that methylation of DNA is an important component in numerous cellular processes, including embryonic development, genomic imprinting, inactivation of $\mathrm{X}$-chromosome, and maintenance of chromosome stability. Hypermethylation of promoter regions ( $\mathrm{CpG}$ islands) silences the DNA repair, cell cycle, and apoptosis pathways genes, whereas hypomethylation of a $\mathrm{CpG}$ dinucleotide in the global genome activates gene expressions (Robertson, 2005). Researchers have also observed that errors in DNA methylation/demethylation were associated with a variety of disturbing consequences, including several human diseases such as cancer. DNA hyper- and hypomethylation play a significant role in cancer progression. It was well-established that DNA hypermethylation often silenced the tumor suppressor genes in cancer cells, while the DNA is hypomethylated in cancer cells as compared to normal cells (Robertson, 2005). ENMs that are commonly used in various biomedical applications were shown to induce epigenetic toxicity by promoting alteration in DNA methylation profile. We summarized these in vitro, in vivo studies or clinical samples showing DNA methylation in Table 1.

In an experiment conducted on HT22 mouse hippocampal neurons, Ag-NPs exposure stimulated the DNA damage response through oxidants alongside changes in methylation patterns of DNA. A significant increment has been reported in the expression levels of DNA methyltransferase (DNMT1, 2, 3a, and 3b) and 5-hmC (Mytych et al., 2017). A significant DNA hypermethylation was reported in Bcl-2 and CREB3L1 and 5-aza (methyltransferase inhibitor), proving that hypermethylation is linked with Bcl-2 and CREB3L1 mRNAs downregulation. The results of this study showed that SiNPs triggered the mitochondrial-mediated apoptosis through $\mathrm{PI} 3 \mathrm{~K} / \mathrm{Akt} / \mathrm{CREB} / \mathrm{Bcl}-2$ signaling pathway and its long term exposure can lead to cancer progression (Zou et al., 2016). Oral administration of PVP-coated $\mathrm{Ag}$ in mice induces genomic instability and DNA damage in multiple tissues, such as in peripheral blood and/or bone marrow and developing embryos, and which may cause permanent genome alterations leading to cancers (Kovvuru et al., 2015). Nallanthighal et al. orally administrated citrate-coated $\mathrm{Ag}$ in wild type and Ogg1 (8-Oxoguanine DNA glycosylase 1) deficient mice showed genotoxicity in both the strains (Nallanthighal et al., 2017). The Ogg1 deficiency showcased exacerbated DNA damage repair. The data suggest that humans with polymorphisms and/or mutations in OGG1 gene are susceptible to Ag ENM mediated damage, which may lead to cancers.

In a study on workers $(n=24)$ with occupational exposure to multi-wall carbon nanotubes (MWCNT) and unexposed controls $(n=43)$ from the same workplace in the blood cells have shown changes in the DNA methylation (Ghosh et al., 2016, 2017). They observed significant methylation changes in DNMT1, ATM, SKI, and HDAC4 promoter CpGs of MWCNT exposed workers, which proves the fact that these occupational exposures may cause epigenetic changes which could produce deleterious effects in future, which may be inherited to the next generation as well. Additionally, these epigenetic misregulations through ENMs may also lead to some lifestyle diseases, which is the critical link for the genotype and phenotype modulations. Although CNTs alone can't bind the DNA, its functionalization (both covalent and non-covalent) with positive charge can effectively condense DNA (Zhou et al., 2013). Hence functionalization of CNTs can lead to epigenetics effects, which need to be studied in detail for further validation in biological systems. Additionally, Aminemodified graphene QDs (AG-QDs) have the ability to enter the nucleus and intercalate with the DNA and it has been known that the intercalating agents have the ability to inhibit the DMNTs, which leads to alterations in genomic DNA methylation patterns leading to epigenetic changes (Lu L. et al., 2016; Castillo-Aguilera et al., 2017; Xu et al., 2018). Hence further experiments are needed in this direction to arrive at the conclusion regarding probable graphene QDs inhibition of DMNTs which may finally affect the cellular environment through epigenetic changes.

$\mathrm{BALB} / \mathrm{c}$ mice intra-tracheal administration of citrate-coated AuNPs (5, 60, and $250 \mathrm{~nm}$ ) resulted in both hypomethylation of GPX gene and hypermethylation of ATM, CDK, and GSR genes in the lung tissues (Tabish et al., 2017). The proteins coded by ATM, CDK, and GSR genes regulate the cell cycle, DNA damage sensing, and transcription in response to several intra- and extra-cellular signals whereas GPX gene encodes an enzyme that helps in reducing oxidative stress and retain the redox homeostasis inside the cell (Deponte, 2013; Malumbres, 2014). Hence, hypomethylation and hypermethylation in their respective genes may lead to lung cancer through epigenetic effects. It was reported that DNA demethylation patterns can also be altered by antioxidant-based chiral AuNPs by directly affecting key DNA demethylating enzymes. AuNPs have the ability to alleviate mRNA expression of TET1 and TET2 alongside up- and down-regulation of different miRNAs, a decreased 5-hmC and HDAC activity (Ma et al., 2016). Upon CuO-NPs administration, LINE-1 methylation has been reduced in RAW264.7, while THP1 and SAEC cell line showed modestly increased methylation profile in Alu and LINE-1 sequences. The reduction in LINE-1 methylation due to $\mathrm{CuO}-\mathrm{NPs}$ exposure caused enhanced Alu-1 and SINE repetitive elements transcription followed by TET1, TET2, and TET3 expression reduction in mouse macrophages (Lu et al., 2016b). Based on these studies, we can conclude that ENMs trigger de-regulation of genes involved in DNA methylation/demethylation reactions, as well as changes of genespecific methylation of tumor suppressor genes, inflammatory genes, and DNA repair genes, eventually leading to cancer growth and development. Gold nanorods (GNR) were reported to be nontoxic, and gain access to the cytoplasmic vesicles following endocytosis without any nuclear localization (Chithrani et al., 2006; Qiu et al., 2010). On the contrary, a study by Hauck et al. reported alteration in gene expression by an unknown 
TABLE 1 | Summary of the key findings asserted by several in vitro, in vivo studies and clinical samples displaying epigenetic changes through DNA modifications induced by the exposure of engineered metallic and non-metallic nanomaterials.

\begin{tabular}{|c|c|c|c|c|c|c|}
\hline $\begin{array}{l}\text { NPs and } \\
\text { functionalization }\end{array}$ & $\begin{array}{l}\text { Characteristics size } \\
(\mathrm{nm}) \text {, zeta potential }\end{array}$ & $\begin{array}{l}\text { Experimental setup } \\
\text { and exposure time }\end{array}$ & Biological model & Epigenetic effects & Year & References \\
\hline $\begin{array}{l}\text { Gold (Colloidal AuNPs } \\
\text { coated with citrate) }\end{array}$ & 5,60 , and $250 \mathrm{~nm}$ & $\begin{array}{l}\text { In-vivo } \\
48 \mathrm{~h}\end{array}$ & $\begin{array}{l}\text { BALB/c mice (Single } \\
\text { Intratracheal } \\
\text { administration) }\end{array}$ & $\begin{array}{l}\text { Lung tissue; hypomethylation of } \\
\text { GPX and several genes, } \\
\text { hypermethylation in ATM, CDK, and } \\
\text { GSR genes }\end{array}$ & 2017 & $\begin{array}{l}\text { Tabish et al., } \\
2017\end{array}$ \\
\hline $\begin{array}{l}\text { Gold (Colloidal AuNPs } \\
\text { coated with citrate) }\end{array}$ & 5,60 , and $250 \mathrm{~nm}$ & $\begin{array}{l}\text { In-vivo } \\
48 \mathrm{~h}\end{array}$ & $\begin{array}{l}\text { BALB/c mice (Single } \\
\text { Intratracheal } \\
\text { administration) }\end{array}$ & $\begin{array}{l}\text { Lung tissue; hypomethylation of } \\
\text { GPX and several genes, } \\
\text { hypermethylation in ATM, CDK, and } \\
\text { GSR genes }\end{array}$ & 2017 & $\begin{array}{l}\text { Tabish et al., } \\
2017\end{array}$ \\
\hline $\begin{array}{l}\text { AgNPs using extracts of } \\
\text { Bacillus cereus }\end{array}$ & $8 \mathrm{~nm}$ & $\begin{array}{l}\text { In-vivo } \\
\text { Intravenous infusion at } \\
1 \mathrm{mg} / \mathrm{kg} \text { doses at } 6.5 \\
\text { days postcoitum }\end{array}$ & $\begin{array}{l}8 \text { week mice with ICR } \\
\text { (imprinting control region) }\end{array}$ & $\begin{array}{l}\text { In placenta tissue, decreased ZAC1 } \\
\text { gene promoter DNA methylation }\end{array}$ & 2015 & $\begin{array}{l}\text { Zhang et al., } \\
2015\end{array}$ \\
\hline AgNPs & $\begin{array}{l}50 \pm 5.0 \mathrm{~nm} \text { (TEM) } \\
55 \pm 6.0 \mathrm{~nm} \text { (water) } \\
-25.2 \pm 0.1 \mathrm{mV}\end{array}$ & $\begin{array}{l}\text { In-vitro } \\
24 \mathrm{~h}\end{array}$ & $\begin{array}{l}\text { Mouse Embryonic } \\
\text { Fibroblast Cells (NIH3T3) }\end{array}$ & $\begin{array}{l}\text { Apoptosis and nucleosome } \\
\text { assembly gene expression } \\
\text { alterations } \\
\text { Gene ontology analysis revealed } \\
\text { alterations in nucleosome assembly } \\
\text { and DNA methylation }\end{array}$ & 2018 & $\begin{array}{l}\text { Gurunathan } \\
\text { et al., } 2018\end{array}$ \\
\hline $\mathrm{ZnO}$ & $90 \mathrm{~nm}$ & $\begin{array}{l}\text { In-vitro } \\
48 \mathrm{~h}\end{array}$ & HEK-293 cells & $\begin{array}{l}\text { Enhanced expression of TET1 and } \\
\text { TET2 genes beside reduction in } \\
5-\mathrm{mC} \text { and escalation in 5-hmC } \\
\text { content }\end{array}$ & 2017 & $\begin{array}{l}\text { Choudhury } \\
\text { et al., } 2017\end{array}$ \\
\hline $\mathrm{ZnO}$ & $<100 \mathrm{~nm}$ & $\begin{array}{l}\text { In-vitro } \\
24 \text { and } 48 \mathrm{~h}\end{array}$ & MRC5 cells & $\begin{array}{l}\text { DNA hypomethylation followed by } \\
\text { DNMTs activity decline beside } \\
\text { reduction in expression levels of } \\
\text { endogenous DNMT1 and } 3 \mathrm{~A}\end{array}$ & 2016 & $\begin{array}{l}\text { Patil et al., } \\
2016\end{array}$ \\
\hline $\mathrm{ZnO}$ & $\begin{array}{l}<100 \mathrm{~nm} \\
-12.46 \pm 0.28 \mathrm{mV}\end{array}$ & $\begin{array}{l}\text { In-vitro } \\
6 \text { and } 24 h\end{array}$ & $\begin{array}{l}\text { Hamster lung fibroblast } \\
(\mathrm{V}-79) \text { cell lines }\end{array}$ & $\begin{array}{l}\text { HGPRT gene showed a remarkable } \\
\text { increase in the mutation frequency } \\
\text { along with DNA damage }\end{array}$ & 2019 & $\begin{array}{l}\text { Jain et al., } \\
2019\end{array}$ \\
\hline $\mathrm{CuO}$ & $\begin{array}{l}58.7 \mathrm{~nm} \\
-21.4 \pm 1.60 \mathrm{mV}\end{array}$ & $\begin{array}{l}\text { In-vitro } \\
24 \mathrm{~h}\end{array}$ & $\begin{array}{l}\text { Human small airway } \\
\text { epithelial cells (SAEC) } \\
\text { and human and murine } \\
\text { macrophages (THP-1 } \\
\text { and RAW264.7) }\end{array}$ & $\begin{array}{l}\text { L1 and Alu showed } \\
\text { hypermethylation, ORF1, ORF2, } \\
\text { SINE B1, and SINE B2 reactivated } \\
\text { in RAW264.7. Alterations reported } \\
\text { in the gene expression of DNMT1 } \\
\text { and TET3 }\end{array}$ & 2016 & $\begin{array}{l}\text { Lu et al., } \\
2016 a\end{array}$ \\
\hline CuNP & $\begin{array}{l}40-60 \mathrm{~nm} \\
-30.3 \mathrm{mV}(\mathrm{PBS}) \\
-38.3 \mathrm{mV}(\mathrm{pH} 5)\end{array}$ & $\begin{array}{l}\text { In-vivo } \\
4 \text { weeks through diet }\end{array}$ & Male albino Wistar rats & $\begin{array}{l}\text { A significant decline was observed } \\
\text { in the level of global DNA } \\
\text { methylation. Reduction in dietary Cu } \\
\text { enhances global DNA methylation }\end{array}$ & 2018 & $\begin{array}{l}\text { Ognik et al., } \\
2019\end{array}$ \\
\hline Anatase $\mathrm{TiO}_{2}$ & $\begin{array}{l}22.1 \mathrm{~nm} \\
-4.47 \pm 0.409 \mathrm{mV}\end{array}$ & $\begin{array}{l}\text { In-vitro } \\
24 \mathrm{~h}\end{array}$ & A549 cells & PARP1 promoter hypermethylated & 2015 & $\begin{array}{l}\text { Bai et al., } \\
2015\end{array}$ \\
\hline $\mathrm{TiO}_{2}$ & $21 \mathrm{~nm}$ & $\begin{array}{l}\text { In-vitro } \\
24 \mathrm{~h}\end{array}$ & $\begin{array}{l}\text { THP-1, RAW264.7 and } \\
\text { SAEC }\end{array}$ & $\begin{array}{l}\text { Methylation levels of SINE } 1 \text { and } \\
\text { expression of TET2 were enhanced }\end{array}$ & 2016 & $\begin{array}{l}\text { Lu et al., } \\
2016 a\end{array}$ \\
\hline $\mathrm{TiO}_{2}$ & $<100 \mathrm{~nm}$ & $\begin{array}{l}\text { In-vitro } \\
24 \text { and } 48 h\end{array}$ & MRC5 cells & $\begin{array}{l}\text { Hypomethylation of the DNA and } \\
\text { reduction in the DNMT activity as } \\
\text { well as expression levels of } \\
\text { endogenous DNMT1, 3A, and 3B }\end{array}$ & 2016 & $\begin{array}{l}\text { Patil et al., } \\
2016\end{array}$ \\
\hline $\mathrm{TiO}_{2}$ & $<100 \mathrm{~nm}$ & $\begin{array}{l}\text { In-vitro } \\
24 \mathrm{~h}\end{array}$ & HaCaT cell line & $\begin{array}{l}\text { Methionine deficiency and } \\
\text { perturbation in the methylation cycle }\end{array}$ & 2013 & $\begin{array}{l}\text { Tucci et al., } \\
2013\end{array}$ \\
\hline $\mathrm{TiO}_{2}$ & $\begin{array}{l}25 \mathrm{~nm} \text { (nanotube } \\
\text { morphology) } \\
\text { or } 60 \mathrm{~nm} \\
\text { (Anastase Morphology) }\end{array}$ & $\begin{array}{l}\text { In-vitro } \\
48 \mathrm{~h}\end{array}$ & $\begin{array}{l}\text { Human Bronchial } \\
\text { Epithelial ( } 16 \text { HBE) and } \\
\text { A549 cells }\end{array}$ & $\begin{array}{l}\text { Anatase-type NPs led to a decline in } \\
\text { global DNA methylation. Expression } \\
\text { levels of methylation related genes } \\
\text { and proteins were also altered } \\
\text { causing epigenomic toxicity }\end{array}$ & 2017 & $\begin{array}{l}\text { Ma et al., } \\
2017\end{array}$ \\
\hline $\mathrm{SiO}_{2}$ & $15 \mathrm{~nm}$ & $\begin{array}{l}\text { In-vitro } \\
24 \mathrm{~h}\end{array}$ & HaCaT cell line & $\begin{array}{l}\text { DNMT 1, DNMT 3a and MBD2 } \\
\text { gene and protein expression } \\
\text { showed a dose-dependent decline. } \\
\text { Global hypomethylation observed }\end{array}$ & 2010 & $\begin{array}{l}\text { Gong et al., } \\
2010\end{array}$ \\
\hline
\end{tabular}


TABLE 1 | Continued

\begin{tabular}{|c|c|c|c|c|c|c|}
\hline $\begin{array}{l}\text { NPs and } \\
\text { functionalization }\end{array}$ & $\begin{array}{l}\text { Characteristics size } \\
(\mathrm{nm}), \text { zeta potential }\end{array}$ & $\begin{array}{l}\text { Experimental setup } \\
\text { and exposure time }\end{array}$ & Biological model & Epigenetic effects & Year & References \\
\hline & & & HaCaT cell line & $\begin{array}{l}\text { Hypermethylation of PARP-1 and } \\
\text { repression of gene expression }\end{array}$ & 2012 & $\begin{array}{l}\text { Gong et al., } \\
2012\end{array}$ \\
\hline & & & $\begin{array}{l}\text { Primary and immortalized } \\
\text { (BEAS 2B) human } \\
\text { bronchial epithelial cells } \\
\text { exposure over } 30 \\
\text { passages }\end{array}$ & $\begin{array}{l}\text { Promoters of } 32 \text { genes showed } \\
\text { Differentially Methylated Regions. } \\
\text { CREB3L1 and BCL2 DNA showed } \\
\text { hypermethylation }\end{array}$ & 2014 & $\begin{array}{l}\text { Zou et al., } \\
2016\end{array}$ \\
\hline $\begin{array}{l}\text { Carbon Nanotubes } \\
\text { C60 MWCNTs }\end{array}$ & $1 \mathrm{~nm}$ & $\begin{array}{l}\text { In-vitro } \\
24 \mathrm{~h}\end{array}$ & A549 cells & $\begin{array}{l}\text { Global DNA methylation levels were } \\
\text { significantly elevated. }\end{array}$ & 2016 & $\begin{array}{l}\text { Li et al., } \\
2016\end{array}$ \\
\hline SWCNTS & $1.2-1.5 \mathrm{~nm}$ & $\begin{array}{l}\text { In-vivo } \\
48 \mathrm{~h}\end{array}$ & $\begin{array}{l}\text { Male BALB/c mice, } \\
\text { single intratracheal } \\
\text { administration }\end{array}$ & $\begin{array}{l}\text { The promoter of the ATM gene } \\
\text { showed little hypomethylation }\end{array}$ & 2017 & $\begin{array}{l}\text { Tabish et al., } \\
2017\end{array}$ \\
\hline MWCNTS & $\begin{array}{l}\text { 5-15 mm long, } \\
27 \mathrm{~nm} \text { diameter }\end{array}$ & $\begin{array}{l}\text { In-vivo } \\
\text { Acute }(24 \mathrm{~h}) \text { and } \\
\text { Subchronic ( } 7 \\
\text { days) post-exposure }\end{array}$ & C57BL/6 mice & $\begin{array}{l}\text { Increased IFN- } \gamma \text { and TNF- } \alpha \text { gene } \\
\text { expression (due to hypomethylation } \\
\text { of the promoter), decreased Thy-1 } \\
\text { (hypermethylation of the promoter) } \\
\text { Both lung and blood showed } \\
\text { global hypomethylation }\end{array}$ & 2016 & $\begin{array}{l}\text { Brown et al., } \\
2016\end{array}$ \\
\hline SWCNTs and MWCNTs & $\begin{array}{l}\text { SWCNTs }(2 \mathrm{~nm}) \\
\text { MWCNTs }(2-100 \mathrm{~nm})\end{array}$ & $\begin{array}{l}\text { In-vitro } \\
24 \mathrm{~h}\end{array}$ & THP-1 cells & $\begin{array}{l}\text { CNTs induced gene } \\
\text { promoter-specific altered } \\
\text { methylation leads to } \\
\text { hypomethylation of } 1,127 \text { different } \\
\text { genes }\end{array}$ & 2016 & $\begin{array}{l}\text { Öner et al., } \\
2016\end{array}$ \\
\hline Nano-Hydroxyapatite & $100 \times 10 \mathrm{~nm}$ & $\begin{array}{l}\text { In-vitro } \\
72 \mathrm{~h}\end{array}$ & $\begin{array}{l}\text { Murine bone marrow } \\
\text { stromal cells (BMSCs), } \\
\text { Pre-osteoblast } \\
\text { MC3T3-E1 cells and } \\
\text { Murine osteocyte, } \\
\text { MLO-Y4 cells }\end{array}$ & $\begin{array}{l}\text { Pro-osteoblastic marker genes ALP, } \\
\text { BSP, and OSC are down-regulated, } \\
\text { while upregulation in OPN }\end{array}$ & 2015 & $\begin{array}{l}\text { Ha et al., } \\
2015\end{array}$ \\
\hline $\begin{array}{l}\text { Anionic cadmium } \\
\text { telluride QDs } \\
\text { (CdTe-QDs) }\end{array}$ & $\begin{array}{l}2.2 \mathrm{~nm} \text { (green-emitting) } \\
\text { and } 5.2 \mathrm{~nm} \text { (Red } \\
\text { emitting) }\end{array}$ & $\begin{array}{l}\text { In-vitro } \\
24 \mathrm{~h}\end{array}$ & $\begin{array}{l}\text { PC12 and N9 murine } \\
\text { microglial cells }\end{array}$ & $\begin{array}{l}\text { Cell death characterized by the } \\
\text { condensation of chromatin and } \\
\text { blebbing of membrane }\end{array}$ & 2005 & $\begin{array}{l}\text { Lovrić et al., } \\
2005\end{array}$ \\
\hline $\begin{array}{l}\text { Modified nano-graphene } \\
\text { quantum dots (M-GQDs) }\end{array}$ & $5-15 \mathrm{~nm}$ & $\begin{array}{l}\text { In-vivo } \\
7 \text { days }\end{array}$ & Zebrafish & $\begin{array}{l}\text { Increase in global DNA } \\
\text { hypermethylation. }\end{array}$ & 2019 & $\begin{array}{l}\text { Hu et al., } \\
2019\end{array}$ \\
\hline GQD & $3.5 \mathrm{~nm}$ & ssDNA & APC gene sequence & $\begin{array}{l}\text { Methylated DNA showed B to A } \\
\text { structure transition }\end{array}$ & 2019 & $\begin{array}{l}\text { Rafiei et al., } \\
2019\end{array}$ \\
\hline SWCNTs and MWCNTs & & $\begin{array}{l}\text { In-vitro } \\
24 \mathrm{~h}\end{array}$ & 16 HBE cells & $\begin{array}{l}\text { SWCNT: DNMT1, NPAT/ATM, } \\
\text { PIK3R2 and MYO1C showed } \\
\text { prominent changes in } \\
\text { sequence-specific methylation in at } \\
\text { least one CpG site } \\
\text { MWCNT: HDAC4, NPAT/ATM, } \\
\text { MAP3K10 and PIK3R2 showed } \\
\text { prominent changes in } \\
\text { sequence-specific methylation in at } \\
\text { least one CpG site }\end{array}$ & 2018 & $\begin{array}{l}\text { Ghosh et al., } \\
2018\end{array}$ \\
\hline $\begin{array}{l}\text { Chiral Au nanoclusters } \\
\text { capped with GSH }\end{array}$ & $4-5 \mathrm{~nm}$ & $\begin{array}{l}\text { In-vitro } \\
24 \mathrm{~h}\end{array}$ & $\begin{array}{l}\text { Human gastric cancer } \\
\text { (MGC- 803) cell line and } \\
\text { Human embryonic kidney } \\
\text { (HEK 293FT) cell line }\end{array}$ & $\begin{array}{l}\text { TET proteins gene downregulation } \\
\text { and decrease of } \\
\text { 5-hydroxymethylcytosine and } \\
\text { Histone Deacetylase (HDAC) activity }\end{array}$ & 2016 & $\begin{array}{l}\text { Ma et al., } \\
2016\end{array}$ \\
\hline MWCNTS & $\begin{array}{l}(200-100 \mathrm{~nm} \\
\text { agglomerates) }\end{array}$ & Clinical samples & $\begin{array}{l}\text { MWCNTs exposed } \\
\text { workers }(n=24) \text { from a } \\
\text { factory and unexposed } \\
\text { controls ( } n=43)\end{array}$ & $\begin{array}{l}\text { Remarkable changes in the } \\
\text { methylation of CpG sites in the } \\
\text { promoter region of DNMT1, } \\
\text { HDAC4, NPAT/ATM, and SKI were } \\
\text { observed }\end{array}$ & 2017 & $\begin{array}{l}\text { Ghosh et al., } \\
2017\end{array}$ \\
\hline SWCNTs and MWCNTs & & $\begin{array}{l}\text { In-vitro } \\
24 \mathrm{~h}\end{array}$ & 16 HBE cells & $\begin{array}{l}\text { MWCNT: HDAC4, NPAT/ATM, } \\
\text { MAP3K10 and PIK3R2 showed } \\
\text { prominent changes in } \\
\text { sequence-specific methylation in at } \\
\text { least one CpG site }\end{array}$ & 2018 & $\begin{array}{l}\text { Ghosh et al., } \\
2018\end{array}$ \\
\hline
\end{tabular}


mechanism following GNR exposure (Hauck et al., 2008). But a recent finding by $\mathrm{Ho}$ et al. concluded that the intracellular speciation of GNR alters the dynamic microenvironment by their interactions within the nucleus leading to structural alterations in genomic DNA, which may trigger changes in the gene expression in cells due to the modified oxidation state of $\mathrm{Au}$ [ $\mathrm{Au}(0)$ to $\mathrm{Au}$ (I)] (Ho et al., 2018). In another study, Conde et al. showed that the ENM of Au with PEG and protamine (AuNP-PEG-Prot) can modify the plasmid DNA topology acting like a histonemimetic, affecting the DNA condensation and decondensation in addition to altering DNA conformation and encouraging structural changes (Conde et al., 2012). Nash et al. showed that any alteration in the charge of the AgNPs causes DNA bends through periodic variation in groove widths and depths, while RNA bends through the expansion of the major groove (Nash et al., 2015). All these results sum up the fact that the gold ENMs have a major influence on the microenvironment of nucleus leading to the epigenetic changes.

\section{ENMs Mediated Histone Modifications}

It is well-established that PTMs of histones mediates a variety of essential biological processes, usually via chromatin remodeling leading to expression or repression of target genes (Dong and Weng, 2013). Incorrect targeting of histone-modifying enzymes, such as HDACs, HATs, HMTs, and HDMs, is often accountable for the abnormal PTMs of histone. HDACs, for example, are often found to be over-expressed in different cancers. HDAC1 was shown to be associated with the tumor suppressor retinoblastoma protein $(\mathrm{Rb})$, and in cooperation with $\mathrm{Rb}$ lead to the repression of transcription factor E2Fregulated promoter of the gene encoding the cell-cycle protein cyclin E. Abnormal regulation of histone methyltransferases or demethylases in cancer cells also contributes to abnormal histone PTMs patterns (Chervona and Costa, 2012). The effect of ENMs on histone PTMs has been less studied as compared to DNA methylation. However, some researchers suggest that histone modifications are also important molecular targets to understand the toxicity mechanism of different types of ENMs. For example, a study on mouse erythroleukemia cells when exposed to AgNPs, showed a significant reduction in the methylation at lysine residues $\mathrm{H} 3 \mathrm{~K} 4$ and $\mathrm{H} 3 \mathrm{~K} 79$ on the b-globin locus, which decreases the histone methyltransferase DOT-1L and MLL levels as well as the direct binding between AgNPs and $\mathrm{H} 3 / \mathrm{H} 4$, which finally decreased the hemoglobin production (Qian et al., 2015). The exposure of AgNPs on HaCaT cells, Human lung and breast adenocarcinoma cells showed enhanced phosphorylation of histone $\mathrm{H} 3$ at serine $10(\mathrm{p}-\mathrm{H} 3 \mathrm{~S} 10)$ in a mitosis independent manner due to activation of Aurora Kinase. It has been found that AgNPs induce the formation of globular actin in a dose-dependent manner after incorporating into the inner cells followed by activation of Aurora Kinase (Zhao et al., 2017) and A549 cells showed enhanced phosphorylation at 10th serine residue in $\mathrm{H} 3(\mathrm{p}-\mathrm{H} 3 \mathrm{~S} 10)$ involving MAPK pathway (Zhao et al., 2019). In a study by Gao et al. (2016), enhanced $\mathrm{H} 3 \mathrm{~K} 9$ methylation and a decrease in H4K5 acetylation were seen on exposure of $\mathrm{ZnO}$ to the HaCaT cells. Anionic CdTeQDs, when exposed to THP-1 cells for 4 and $24 \mathrm{~h}$, exerted their binding to core histones changing their physical and chemical properties leading to an enhanced aggregate formation (Conroy et al., 2008). While, the uncharged CdTe-QDs showed global hypoacetylation in the histone 3 leading to chromatin decondensation in MCF-7 at 4 and $24 \mathrm{~h}$ (Choi et al., 2008). When human recombinant histone deacetylase 8 enzyme-treated by a colloid solution of gold, the Au binds $-\mathrm{SH}$ group on the surface of enzyme and decreases its activity, which may lead to compromised function in the cells leading to epigenetic changes (Sule et al., 2008). The exposure of Au particles on HeLa cells enhances the connection of core histones and lamin protein due to modulation of heterochromatin (Mazumder and Shivashankar, 2007). Zhang et al. reported that the exposure of $\mathrm{SiO}_{2}$ on the A549 cells decreases SIRT6 expression, leading to the upregulation of FST levels due to suppressed deacetylation of H3K9 and H3K56 at FST promoter (Zhang L. et al., 2018). It is concluded from this study FST transcription is negatively regulated by SIRT6 and participates in the regulation of cell particle during $\mathrm{SiO}_{2}$ exposure. All these studies shown in Table 2 have clearly observed the histone-based modifications leading to altered promoter expressions with a little or no knowledge on gene enhancers due to their respective ENMs exposures, which are mainly involved in regulating development and cell differentiation.

\section{ENMs Mediated De-regulation of Non-protein-coding RNAs}

The epigenetic machinery is greatly influenced by the presence of regulatory non-protein-coding RNAs (ncRNAs), which play a crucial part in the regulation of gene expression through their dynamic interactions with DNA, RNA, and proteins leading to various epigenetic modifications (Frías-Lasserre and Villagra, 2017). The regulatory non-protein-coding RNAs (ncRNAs) can be categorized into long ncRNAs (larger transcripts) and short ncRNAs ( $<200$ nucleotides). The different subtypes of short ncRNAs include miRNAs, endogenous siRNAs, and piRNAs. The lncRNAs are natural antisense transcripts, or sense intronic RNAs, or long intergenic noncoding RNAs (Peschansky and Wahlestedt, 2014). These RNAs have a multitude of functions in cells, and it is well-researched that about one-quarter of the human genes engaged are regulated by miRNAs are involved in tumorigenesis, cardiovascular and developmental disorders, neurological and other diseases (Portela and Esteller, 2010; Paul et al., 2018). Non-protein coding RNAs can modify gene expression by interacting with other epigenetic machinery, similar to alteration in DNA methylation by regulation of DNMTs, modulating the expression and function of histone modifier proteins, and/or chromatin remodeling. ncRNAs are highly flexible and dynamic in interacting with DNA, RNA, and proteins (Portela and Esteller, 2010; Paul et al., 2018). These properties make ncRNAs capable of mediating a plethora of epigenetic mechanisms by which the cellular environment will be altered based on various external or internal stimuli. Therefore, it is quite clear that, together with DNA methylation and histone post-translation alteration machinery, regulation of ncRNAs can also be influenced by exposure to ENMs. 
TABLE 2 | Summary of the key findings asserted by several in vitro and in vivo studies displaying epigenetic changes through histone modifications induced by the exposure of engineered metallic and non-metallic nanomaterials.

\begin{tabular}{|c|c|c|c|c|c|c|}
\hline $\begin{array}{l}\text { NPs and } \\
\text { functionalization }\end{array}$ & $\begin{array}{l}\text { Characteristics size } \\
(\mathrm{nm}) \text {, zeta potential }\end{array}$ & $\begin{array}{l}\text { Experimental setup } \\
\text { and exposure time }\end{array}$ & Biological model & Epigenetic effects & Year & References \\
\hline Au particles & $5 \mathrm{~nm}$ & $\begin{array}{l}\text { In-vitro } \\
1 \mathrm{~h}\end{array}$ & HeLa cells & $\begin{array}{l}\text { Heterochromatin modulation connects } \\
\text { core histone and lamin protein }\end{array}$ & 2007 & $\begin{array}{l}\text { Mazumder and } \\
\text { Shivashankar, } \\
2007\end{array}$ \\
\hline A colloid solution of gold & $10 \mathrm{~nm}$ & $\begin{array}{l}\text { Human Recombinant } \\
\text { histone deacetylase } 8 \\
\text { enzyme }\end{array}$ & & $\begin{array}{l}\text { Binds - SH group on the surface of the } \\
\text { enzyme and decreases its activity }\end{array}$ & 2008 & $\begin{array}{l}\text { Sule et al., } \\
2008\end{array}$ \\
\hline $\begin{array}{l}\text { Negatively charged } \\
\text { (citrate-capped) and } \\
\text { positively charged } \\
\text { (cysteamine-capped) } \\
\text { AuNPs }\end{array}$ & $212.7 \mathrm{~nm}-38.7 \mathrm{mV}$ & In-vitro & $\begin{array}{l}\text { Triple-negative breast } \\
\text { cancer (MDA-MB-231 } \\
\text { and MDA-MB-468) } \\
\text { cells }\end{array}$ & $\begin{array}{l}\text {-ve charged NFPs; increased the } \\
\text { expression of MKP-1, } \\
\text { dephosphorylated and deacetylated } \\
\text { histone } \mathrm{H} 3 \text { at Ser10 and K9/ K14 } \\
\text { residues respectively } \\
\text { +ve charged NPs; decreased the } \\
\text { expression of MKP-1, phosphorylated } \\
\text { and acetylated histone H3 at Ser } 10 \\
\text { and K9/K14 residues respectively }\end{array}$ & 2018 & $\begin{array}{l}\text { Surapaneni } \\
\text { et al., } 2018\end{array}$ \\
\hline $\begin{array}{l}\text { AgNPs with } \\
\text { polyvinylpyrrolidone } \\
\text { coating }\end{array}$ & $25 \mathrm{~nm}$ & $\begin{array}{l}\text { In-vitro } \\
72 \mathrm{~h}\end{array}$ & $\begin{array}{l}\text { Mouse erythroleukemia } \\
\text { cells }\end{array}$ & $\begin{array}{l}\text { Methylation of H3 at lysine (Lys) } 4 \\
\text { (H3K4) and Lys } 79 \text { (H3K79) on the } \\
\text { b-globin locus was reduced greatly } \\
\text { Decreased, disruptor of telomeric } \\
\text { silencing 1-like and mixed lineage } \\
\text { leukemia histone methyltransferase } \\
\text { levels beside direct binding of AgNPs } \\
\text { to } \mathrm{H} 3 / \mathrm{H} 4\end{array}$ & 2015 & $\begin{array}{l}\text { Qian et al., } \\
2015\end{array}$ \\
\hline AgNPs & $200 \mathrm{~nm}$ & $\begin{array}{l}\text { In-vitro } \\
24 \mathrm{~h}\end{array}$ & $\begin{array}{l}\text { Human skin } \\
\text { keratinocytes (HaCaT), } \\
\text { Human lung and breast } \\
\text { adenocarcinoma cells } \\
\text { (A549 and MCF-7) }\end{array}$ & $\begin{array}{l}\text { Activation of Aurora kinase, leading to } \\
\text { the induction of phosphorylation of } \\
\text { histone } \mathrm{H} 3 \text { at serine } 10(\mathrm{p}-\mathrm{H} 3 \mathrm{~S} 10) \text { in a } \\
\text { mitosis independent manner }\end{array}$ & 2017 & $\begin{array}{l}\text { Zhao et al., } \\
2017\end{array}$ \\
\hline AgNPs & $100 \mathrm{~nm}$ & $\begin{array}{l}\text { In-vitro } \\
10 \mathrm{~h}\end{array}$ & A549 cells & $\begin{array}{l}\text { Phosphorylation of histone } \mathrm{H} 3 \text { at serine } \\
10 \text { (p-H3S10) Involves MAPK pathways } \\
\text { and independent of DNA damage }\end{array}$ & 2019 & $\begin{array}{l}\text { Zhao et al., } \\
2019\end{array}$ \\
\hline $\mathrm{ZnO}$ & $<100 \mathrm{~nm}$ & $\begin{array}{l}\text { In-vitro } \\
24 \mathrm{~h}\end{array}$ & HaCaT cells & $\begin{array}{l}\text { H3K9 showed a marked increase in } \\
\text { methylation status while H4K5 showed } \\
\text { a decline in acetylation. Along with the } \\
\text { chromatin condensation, HMT G9a } \\
\text { showed up-regulation while HATs } \\
\text { GCN5, P300 and CBP were } \\
\text { downregulated }\end{array}$ & 2016 & $\begin{array}{l}\text { Gao et al., } \\
2016\end{array}$ \\
\hline $\mathrm{SiO}_{2}$ & & $\begin{array}{l}\text { In-vitro } \\
24 \mathrm{~h}\end{array}$ & A549 cells & $\begin{array}{l}\text { Decreased SIRT6 expression, leads to } \\
\text { the upregulation of FST level due to } \\
\text { suppressed deacetylation of H3K9 and } \\
\text { H3K56 at FST promoter }\end{array}$ & 2018 & $\begin{array}{l}\text { Zhang L. et al., } \\
2018\end{array}$ \\
\hline Nanofibrous scaffolds & & In-vitro & $\begin{array}{l}\text { Fibroblasts isolated } \\
\text { from ear tissue of } \\
\text { C57BL/6 mice }\end{array}$ & $\begin{array}{l}\text { The decrease in HDAC activity, } \\
\text { upregulation in the expression of WD } \\
\text { repeat domain } 5 \text { (WDR5) with } \\
\text { increasing H3 methylation and } \\
\text { acetylation }\end{array}$ & 2013 & Ha et al., 2015 \\
\hline $\begin{array}{l}\text { Soft NMs } \\
\text { Cholesterylbutyrate solid } \\
\text { lipid NPs releasing } \\
\text { butyric acid }\end{array}$ & $100-150 \mathrm{~nm}$ & In-vitro and In-vivo & $\begin{array}{l}\text { Cancer cell lines and } \\
\text { Rat intracerebral } \\
\text { glioma model }\end{array}$ & Inhibition of HDACs & 2008 & $\begin{array}{l}\text { Brioschi et al., } \\
2008\end{array}$ \\
\hline $\begin{array}{l}\text { Soft NMs K- } 182 \\
\text { HDACl-coated cationic } \\
\text { NPs }\end{array}$ & $\begin{array}{l}137.9-176.7 \mathrm{~nm} \\
64.0-63.0 \mathrm{mV}\end{array}$ & $\begin{array}{l}\text { In-vitro } \\
24 \mathrm{~h}\end{array}$ & $\begin{array}{l}\text { Human prostate cancer } \\
\text { (PC-3) cells and human } \\
\text { breast cancer (Sk-Br-3) } \\
\text { cells }\end{array}$ & $\begin{array}{l}\text { Remarkably high gene expression and } \\
\text { hyperacetylation of the core histones }\end{array}$ & 2009 & $\begin{array}{l}\text { Ishii et al., } \\
2009\end{array}$ \\
\hline Anionic CdTe-QDs & $3.4 \mathrm{~nm}$ & $\begin{array}{l}\text { In-vitro } \\
4 \text { or } 24 \mathrm{~h}\end{array}$ & THP-1 cells & $\begin{array}{l}\text { NPs binding to core histones changes } \\
\text { their physical and chemical properties } \\
\text { leading to an increase in aggregate } \\
\text { formation }\end{array}$ & 2008 & $\begin{array}{l}\text { Conroy et al., } \\
2008\end{array}$ \\
\hline CdTe-QDs & & $\begin{array}{l}\text { In-vitro } \\
4 \text { or } 24 \text { h }\end{array}$ & MCF-7 cells & $\begin{array}{l}\text { Deacetylation of Histone } 3 \text { leads to } \\
\text { chromatin decondensation (global } \\
\text { hypoacetylation) }\end{array}$ & 2008 & $\begin{array}{l}\text { Choi et al., } \\
2008\end{array}$ \\
\hline
\end{tabular}




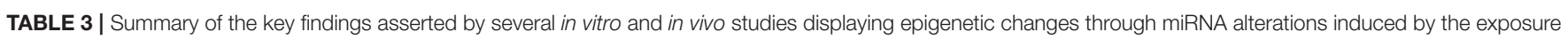
of engineered metallic and non-metallic nanomaterials.

\begin{tabular}{|c|c|c|c|c|c|c|}
\hline $\begin{array}{l}\text { NPs and } \\
\text { functionalization }\end{array}$ & $\begin{array}{l}\text { Characteristics } \\
\text { size }(\mathrm{nm}), \text { zeta } \\
\text { potential }\end{array}$ & $\begin{array}{l}\text { Experimental setup } \\
\text { and exposure time }\end{array}$ & Biological model & Epigenetic effects & Year & References \\
\hline $\begin{array}{l}\text { AuNPs coated with } \\
\text { citrate }\end{array}$ & $20 \mathrm{~nm}$ & $\begin{array}{l}\text { In-vivo } \\
1 \text { week and } 2 \text { months }\end{array}$ & $\begin{array}{l}\text { Male wistar rats single tail } \\
\text { vein injection of } 0.2 \mathrm{~mL} \\
(15.1 \mathrm{mg} / \mathrm{mL})\end{array}$ & $\begin{array}{l}21 \text { miRNAs dysregulation (miR-298 } \\
\text { upregulated) }\end{array}$ & 2012 & $\begin{array}{l}\text { Chew et al., } \\
2012\end{array}$ \\
\hline $\begin{array}{l}\text { Colloidal AuNPs coated } \\
\text { with citrate }\end{array}$ & $20 \mathrm{~nm}$ & $\begin{array}{l}\text { In-vitro } \\
48 \text { or } 72 \mathrm{~h}\end{array}$ & $\begin{array}{l}\text { Lung fibroblast (MRC5) } \\
\text { cell line }\end{array}$ & $\begin{array}{l}\text { Chromatin condensation, miR-155 } \\
\text { upregulation, PROS1 gene } \\
\text { downregulation }\end{array}$ & 2011 & Ng et al., 2011 \\
\hline $\begin{array}{l}\text { Colloidal AuNPs coated } \\
\text { with citrate }\end{array}$ & $20 \mathrm{~nm}$ & $\begin{array}{l}\text { In-vivo } \\
\text { Transplacental } \\
\text { treatment on gestation } \\
\text { days; 10th, 12th, 14th, } \\
\text { and 17th }\end{array}$ & $\begin{array}{l}\text { Adult female and male } \\
\text { Swiss albino mice }\end{array}$ & $\begin{array}{l}\text { Fetus lung: } 28 \text { miRNAs } \\
\text { dysregulation, let-7, and miR-183 } \\
\text { upregulation } \\
\text { Fetus liver: } 5 \text { miRNAs dysregulation, } \\
\text { let-7, and miR-183 upregulation }\end{array}$ & 2013 & $\begin{array}{l}\text { Balansky et al., } \\
2013\end{array}$ \\
\hline AgNPs & $<100 \mathrm{~nm}$ & $\begin{array}{l}\text { In-vitro } \\
24 \mathrm{~h}\end{array}$ & $\begin{array}{l}\text { Human Jurkat T cell and } \\
\text { Jurkat clone E6-1 }\end{array}$ & $\begin{array}{l}63 \text { miRNAs expression altered and } \\
\text { MT1F and TRIB3 genes expression } \\
\text { is - vely correlated with miR-219-5p }\end{array}$ & 2014 & $\begin{array}{l}\text { Eom et al., } \\
2014\end{array}$ \\
\hline AgNPs & $23 \mathrm{~nm}$ & $\begin{array}{l}\text { In-vitro } \\
24 \mathrm{~h}\end{array}$ & $\begin{array}{l}\text { Mouse osteoblastic cells } \\
\text { (MC3T3-E1 bone cells) }\end{array}$ & $\begin{array}{l}\text { Altered expression of miRNA } \\
\text { resulting in specific gene expression } \\
\text { allied with bone formation }\end{array}$ & 2011 & $\begin{array}{l}\text { Mahmood } \\
\text { et al., } 2011\end{array}$ \\
\hline $\begin{array}{l}\text { Superparamagnetic } \\
\text { iron-oxide nanoparticles } \\
\text { (SPIONs) }\end{array}$ & $4-7 \mathrm{~nm}$ & $\begin{array}{l}\text { In-vitro } \\
24 \mathrm{~h}\end{array}$ & $\begin{array}{l}\text { Rat pheochromocytoma } \\
\text { (PC12) cell line }\end{array}$ & Wide changes in miRNA profile & 2015 & $\begin{array}{l}\text { Sun et al., } \\
2015\end{array}$ \\
\hline $\mathrm{Fe}_{2} \mathrm{O}_{3}$ & & $\begin{array}{l}\text { In-vitro } \\
12 \text { and } 24 \mathrm{~h}\end{array}$ & NIH3T3 cells & $\begin{array}{l}\text { Genome-wide changes in the } \\
\text { miRNAs expression profile }\end{array}$ & 2011 & Li et al., $2011 \mathrm{a}$ \\
\hline SPIONs & $20 \mathrm{~nm}$ & $\begin{array}{l}\text { In-vitro } \\
24 \mathrm{~h}\end{array}$ & $\begin{array}{l}\text { human liver carcinoma } \\
\text { (HepG2) cells }\end{array}$ & $\begin{array}{l}\text { Altered miRNAs expression but } \\
\text { don't affect DNA methylation }\end{array}$ & 2019 & $\begin{array}{l}\text { Brzóska et al., } \\
2019\end{array}$ \\
\hline $\mathrm{Co}_{3} \mathrm{O}_{4} \mathrm{NPs}$ & $\begin{array}{l}17 \mathrm{~nm} \\
-19.1 \mathrm{mV}\end{array}$ & $\begin{array}{l}\text { In-vitro } \\
24 \mathrm{~h}\end{array}$ & A549 cells & $\begin{array}{l}\text { A lower and temporary downfall in } \\
\text { the expression of miR-21, miR-30a. } \\
\text { Levels of miR- } 21 \text { recovered after } \\
24 \mathrm{~h} \text { while miR-30a showed } \\
\text { upregulation. miR-155 levels are } \\
\text { high after } 2-4 \mathrm{~h} \text { but decreased on } \\
\text { longer exposure }\end{array}$ & 2017 & $\begin{array}{l}\text { Alinovi et al., } \\
2017\end{array}$ \\
\hline $\mathrm{TiO}_{2}$ & $<100 \mathrm{~nm}$ & $\begin{array}{l}\text { In-vitro } \\
1 \mathrm{~h} \text { daily for } 11 \\
\text { consecutive days }\end{array}$ & C57BL/6 female mice & $\begin{array}{l}\text { Upregulation in the targeting genes } \\
\text { involved in immune response in the } \\
\text { lungs like miR-1, miR-449a, and } \\
\text { miR-135b }\end{array}$ & 2011 & $\begin{array}{l}\text { Halappanavar } \\
\text { et al., } 2011\end{array}$ \\
\hline $\mathrm{TiO}_{2}$ & $38 \mathrm{~nm}$ & $\begin{array}{l}\text { In-vitro } \\
24 \mathrm{~h}\end{array}$ & A549 cells & $\begin{array}{l}\text { miR-21 and miR-30a showed } \\
\text { significant down-regulation along } \\
\text { with alteration in miR-155 } \\
\text { expression }\end{array}$ & 2017 & $\begin{array}{l}\text { Alinovi et al., } \\
2017\end{array}$ \\
\hline $\mathrm{SiO}_{2}$ & $70 \mathrm{~nm}$ & $\begin{array}{l}4,8,24, \text { or } 72 \mathrm{~h} \text { after } \\
\text { treatment }\end{array}$ & BALB/c mice & $\begin{array}{l}\text { miR-122 and miR-192 showed } \\
\text { upregulation induced by nSP70-C }\end{array}$ & 2013 & $\begin{array}{l}\text { Nagano et al., } \\
2013\end{array}$ \\
\hline MWCNTS & & $\begin{array}{l}\text { Invitro } \\
12 \text { and } 24 \mathrm{~h}\end{array}$ & NIH3T3 cells & $\begin{array}{l}\text { Wide dysregulation was seen in the } \\
\text { expression of miRNAs; three KE GG } \\
\text { pathways are remarkably regulated }\end{array}$ & 2011 & Li et al., $2011 \mathrm{a}$ \\
\hline CdTe-QDs & $1-2.5 \mathrm{~nm}$ & $\begin{array}{l}\text { In-vitro } \\
12 \text { and } 24 \mathrm{~h}\end{array}$ & NIH3T3 cells & $\begin{array}{l}\text { Global alteration of the expression } \\
\text { pattern of miRNAs in cells with } \\
\text { apoptosis-like cell death }\end{array}$ & $\begin{array}{l}2011 \\
2013\end{array}$ & $\begin{array}{l}\text { Li et al., } \\
\text { 2011a,b; Sun } \\
\text { et al., } 2013\end{array}$ \\
\hline
\end{tabular}

Early studies by Halappanavar et al. have established the fact that ENM exposure alters the expression of respective ncRNAs (Halappanavar et al., 2011). Significant changes were observed by them in the expression pattern of 16 miRNAs in lungs tissue of a mouse model subjected to surface-coated nanoTiO 2 . Among another miRNA, the best results were shown by mmu-miR449 in comparison with the native controls. This research also showed that nanoTiO ${ }_{2}$ induces lung inflammation but failed to create a direct connection between miRNA deregulation and pulmonary injury. In another study by $\mathrm{Ng}$ et al. using gold nanoparticles, it was shown that upregulation of miR-155 is naturally accompanied by downregulation of the PROS1 gene coding $S$ protein, a cofactor with great influence on blood clotting processes (Ng et al., 2011). This study gives an insight into the molecular mechanisms and their impact on epigenetic processes through gold nanoparticles toxicity. Significant shifts in miRNA 
expression and transplacental size-dependent clastogenic and epigenetic effects have been observed through AuNP as reported by Balansky et al. in the mouse fetus (Balansky et al., 2013). They observed upregulated expression of 28 miRNAs in the fetal lung and 8 miRNAs in the fetal liver, with miR-183 and Let$7 \mathrm{a}$ upregulated in both the tissues. The cells exposed to Silver NPs showed a negative correlation between the expression of hsamiR-219-5p and TRIB3 and MT1F genes, which are involved in the cell cycle, oxidative stress, and apoptosis (Eom et al., 2014). On the contrary, AuNPs induces MC3T3-E1 bone cell mineralization by altering the expression of targets genes allied with the formation of bone through some specific miRNAs (Mahmood et al., 2011). The exposure of $\mathrm{TiO}_{2} \mathrm{NPs}$ altered the autophagy pathway through long-lasting $(48 \mathrm{~h})$ alleviation of miRNA-21 and miRNA-30a expression. It was also observed that after every $2 \mathrm{~h}$ miR-155 is upregulated, but is subsequently degraded following longer times of exposure (Alinovi et al., 2017). A day-long exposure of iron oxide NPs ( $\mathrm{Fe}_{2} \mathrm{O}_{3} \mathrm{NPs}$ ) in $\mathrm{NIH} / 3 \mathrm{~T} 3$ fibroblast cells induces a change in the 167 miRNAs expression. These epigenetic, genomic and non-genomic cellular changes which have been observed through ENM exposure are summarized in Table 3. All the in vivo and in vitro studies have only summed up the fact that ENMs induce alterations in miRNA expression without going deeply into their associated underlying molecular mechanisms and their assisted repercussions. The role of lncRNA, siRNA, and piRNA in the epigenetic modifications during ENM exposure remain largely unknown.

\section{FUTURE PROSPECTS}

The ENMs are extensively being utilized in various commercial applications and are a constituent of numerous consumer products. Despite being a commercial commodity, many concerns have been raised regarding the potentially harmful effects of ENMs on the environment and human health. ENMs used in personalized medicines remain associated with several health issues and pose a great concern among researchers worldwide to overcome their toxicity. After entering into the human body, ENMs accumulate in the tissues/organs because of their insoluble, non-biodegradable, non-biocompatible nature, thus restricting the pace of excretion, resulting in long-term exposure and subsequent toxicity. ENMs have a tendency to aggregate and form large structures ranging from 5 to $500 \mathrm{~nm}$ in diameter and translocate the lung-blood barrier through an endocytic uptake mechanism and enter the blood circulation. These are transported through the body to various tissues and bodies such as the heart, body, spleen, gastrointestinal tract, cardiac system, and central nervous system where they have damaging impacts on health. Nanomaterials communicate with biomolecules i.e., DNA, proteins, and lipids within the body and altering the fundamental cellular and metabolic processes like cell division, cellular signaling, apoptosis and trigger inflammation epigenetic alteration and modifications in the chromosome. Among various toxicity mechanisms, epigenetic mechanisms are not very well-studied. Here we summarize the toxic effects of various ENMs leading to the epigenetic changes. It was well-established that epigenetic processes shape our development and enable us to adapt to a constantly changing environment. The epigenetic manipulation is associated with several reported disease conditions, such as allergic contact dermatitis, inflammatory bowel disease, childhood asthma, chronic obstructive pulmonary disease, and several type of cancers, neurodegenerative, and genetic disorders. Epigenetic mechanisms are also related with the progression of autoimmune diseases and several other inflammatory disorders like multiple sclerosis, rheumatoid systemic lupus erythematosus, arthritis, psoriasis, Crohn's disease (Smolkova et al., 2018). ENMs are considered potential epimutagens, as they promote neoplastic changes by disrupting epigenetically preserved gene function via global epigenetic processes. Therefore, it is of utmost importance to understand the epigenetic changes induced by ENMs used in personalized nanomedicines. ENM associated toxicity remains a concern in developing the strategies to minimize the negative impacts, thus it is critical to understand why ENMs pose toxicity. Toxicity of ENM is largely dependent on its longterm accumulation in the biological tissues and affinity with biomolecules, which is mainly influenced by functional groups, purity, and size of ENMs. Research activities should be focused on optimizing physicochemical properties from synthesis to purification. Improved in vivo, in vitro, and epidemiological study considering modern molecular-omics strategies utilizing modern techniques and platforms would definitely help to identify detailed epigenetic mechanisms that link, or act as molecular markers of, environmental exposures and human health concerns. We anticipate that having a centralized database on ENMs toxicity in the context of physicochemical properties and a well-established in vivo system will be an added benefit in understanding the nature and extent of toxicity. Finally, there is an urgent need to develop guidelines on minimum concentrations, which could be possible only by establishing close collaboration between scientists from academia and industries, which should be closely monitored by the governmental and regulatory bodies, promoting the research within a regulatory context. These collaborative activities drive the development and implementation of epigenetically relevant integrated testing strategies and policies for the continued protection of public health.

\section{CONCLUSION}

Epigenetic alterations have the potential to induce prolonged changes in the programming of gene expression and any failure in the detection of these changes could lead to unexpected and unpleasant effects in the biological system. ENMs have a little yet strong effect on epigenetics, so it becomes mandatory to scrutinize them before their extensive applications specifically in the biomedical field. Further studies on this subject matter seem necessary in order to outline/strategize an effective nano-focused risk evaluation strategy/approach that consists of more substantial information about ENMs and its interaction with the surroundings including human and environment. 


\section{AUTHOR CONTRIBUTIONS}

PB conceived the idea. $\mathrm{PB}$ and $\mathrm{MG}$ worked on study conception and design. MG, PB, KZ, and PM screened titles for relevance and abstracted the data from the

\section{REFERENCES}

Alexis, F., Pridgen, E., Molnar, L. K., and Farokhzad, O. C. (2008). Factors affecting the clearance and biodistribution of polymeric nanoparticles. Mol. Pharm. 5, 505-515. doi: 10.1021/mp800051m

Alinovi, R., Goldoni, M., Pinelli, S., Ravanetti, F., Galetti, M., Pelosi, G., et al. (2017). Titanium dioxide aggregating nanoparticles induce autophagy and under-expression of microRNA 21 and 30a in A549 cell line: a comparative study with cobalt (II, III) oxide nanoparticles. Toxicol. In Vitro 42, 76-85. doi: 10.1016/j.tiv.2017.04.007

Anselmo, A. C., Zhang, M., Kumar, S., Vogus, D. R., Menegatti, S., Helgeson, M. E., et al. (2015). Elasticity of nanoparticles influences their blood circulation, phagocytosis, endocytosis, and targeting. ACS Nano 9, 3169-3177. doi: 10.1021/acsnano.5b00147

Arvizo, R. R., Miranda, O. R., Thompson, M. A., Pabelick, C. M., Bhattacharya, R., Robertson, J. D., et al. (2010). Effect of nanoparticle surface charge at the plasma membrane and beyond. Nano Lett. 10, 2543-2548. doi: 10.1021/nl101140t

Babele, P. K. (2019). Zinc oxide nanoparticles impose metabolic toxicity by deregulating proteome and metabolome in Saccharomyces cerevisiae. Toxicol. Rep. 6, 64-73. doi: 10.1016/j.toxrep.2018.12.001

Babele, P. K., Singh, A. K., and Shrivastava, A. (2019). Bio-inspired silver nanoparticles impose metabolic and epigenetic toxicity to Saccharomyces cerevisiae. Front. Pharmacol. 10:1016. doi: 10.3389/fphar.2019.01016

Babele, P. K., Thakre, P. K., Kumawat, R., and Tomar, R. S. (2018). Zinc oxide nanoparticles induce toxicity by affecting cell wall integrity pathway, mitochondrial function and lipid homeostasis in Saccharomyces cerevisiae. Chemosphere 213, 65-75. doi: 10.1016/j.chemosphere.2018.09.028

Bai, W., Chen, Y., and Gao, A. (2015). Cross talk between poly (ADPribose) polymerase 1 methylation and oxidative stress involved in the toxic effect of anatase titanium dioxide nanoparticles. Int. J. Nanomed. 10:5561. doi: 10.2147/IJN.S88059

Balansky, R., Longobardi, M., Ganchev, G., Iltcheva, M., Nedyalkov, N., Atanasov, P., et al. (2013). Transplacental clastogenic and epigenetic effects of gold nanoparticles in mice. Mutat. Res. 751, 42-48. doi: 10.1016/j.mrfmmm.2013.08.006

Banerjee, A., Qi, J., Gogoi, R., Wong, J., and Mitragotri, S. (2016). Role of nanoparticle size, shape and surface chemistry in oral drug delivery. J. Control. Release 238, 176-185. doi: 10.1016/j.jconrel.2016.07.051

Behzadi, S., Serpooshan, V., Tao, W., Hamaly, M. A., Alkawareek, M. Y., Dreaden, E. C., et al. (2017). Cellular uptake of nanoparticles: journey inside the cell. Chem. Soc. Rev. 46, 4218-4244. doi: 10.1039/C6CS00636A

Brioschi, A., Zara, G., Calderoni, S., Gasco, M., and Mauro, A. (2008). Cholesterylbutyrate solid lipid nanoparticles as a butyric acid prodrug. Molecules 13, 230-254. doi: 10.3390/molecules13020230

Brown, T. A., Lee, J. W., Holian, A., Porter, V., Fredriksen, H., Kim, M., et al. (2016). Alterations in DNA methylation corresponding with lung inflammation and as a biomarker for disease development after MWCNT exposure. Nanotoxicology 10, 453-461. doi: 10.3109/17435390.2015.1078852

Brzóska, K., Gradzka, I., and Kruszewski, M. (2019). Silver, gold, and iron oxide nanoparticles alter miRNA expression but do not affect DNA methylation in HepG2 cells. Materials 12:1038. doi: 10.3390/ma12071038

Cai, X., Dong, J., Liu, J., Zheng, H., Kaweeteerawat, C., Wang, F., et al. (2018). Multi-hierarchical profiling the structure-activity relationships of engineered nanomaterials at nano-bio interfaces. Nat. Commun. 9:4416. doi: 10.1038/s41467-018-06869-9

Capraro, B. R., Shi, Z., Wu, T., Chen, Z., Dunn, J. M., Rhoades, E., et al. (2013). Kinetics of endophilin N-BAR domain dimerization and membrane interactions. J. Biol. Chem. 288, 12533-12543. doi: 10.1074/jbc.M112.435511 eligible full-text articles. MG, PB, KZ, and PM analyzed and interpreted the data and drafted the manuscript. $\mathrm{PB}$ and MG critically revised the manuscript with input from the entire team. All authors have read and approved the final draft.
Castillo-Aguilera, O., Depreux, P., Halby, L., Arimondo, P., and Goossens, L. (2017). DNA methylation targeting: the DNMT/HMT crosstalk challenge. Biomolecules 7:3. doi: 10.3390/biom7010003

Caviston, J. P., and Holzbaur, E. L. (2006). Microtubule motors at the intersection of trafficking and transport. Trends Cell Biol. 16, 530-537. doi: 10.1016/j.tcb.2006.08.002

Chervona, Y., and Costa, M. (2012). Histone modifications and cancer: biomarkers of prognosis? Am. J. Cancer Res. 2, 589-597.

Chew, W.-S., Poh, K.-W., Siddiqi, N. J., Alhomida, A. S., Yu, L. E., and Ong, W.Y. (2012). Short-and long-term changes in blood miRNA levels after nanogold injection in rats-potential biomarkers of nanoparticle exposure. Biomarkers 17, 750-757. doi: 10.3109/1354750X.2012.727030

Chithrani, B. D., and Chan, W. C. (2007). Elucidating the mechanism of cellular uptake and removal of protein-coated gold nanoparticles of different sizes and shapes. Nano Lett. 7, 1542-1550. doi: 10.1021/nl070363y

Chithrani, B. D., Ghazani, A. A., and Chan, W. C. (2006). Determining the size and shape dependence of gold nanoparticle uptake into mammalian cells. Nano Lett. 6, 662-668. doi: 10.1021/nl052396o

Choi, A. O., Brown, S. E., Szyf, M., and Maysinger, D. (2008). Quantum dotinduced epigenetic and genotoxic changes in human breast cancer cells. J. Mol. Med. 86, 291-302. doi: 10.1007/s00109-007-0274-2

Chompoosor, A., Saha, K., Ghosh, P. S., Macarthy, D. J., Miranda, O. R., Zhu, Z. J., et al. (2010). The role of surface functionality on acute cytotoxicity, ROS generation and DNA damage by cationic gold nanoparticles. Small 6, 2246-2249. doi: 10.1002/smll.201000463

Choudhury, S. R., Ordaz, J., Lo, C.-L., Damayanti, N. P., Zhou, F., and Irudayaraj, J. (2017). From the cover: zinc oxide nanoparticles-induced reactive oxygen species promotes multimodal cyto-and epigenetic toxicity. Toxicol. Sci. 156, 261-274. doi: 10.1093/toxsci/kfw252

Cirio, M. C., Martel, J., Mann, M., Toppings, M., Bartolomei, M., Trasler, J., et al. (2008). DNA methyltransferase 1o functions during preimplantation development to preclude a profound level of epigenetic variation. Dev. Biol. 324, 139-150. doi: 10.1016/j.ydbio.2008.09.015

Conde, J., Baptista, P. V., Hernández, Y., Sanz, V., and De La Fuente, J. M. (2012). Modification of plasmid DNA topology by 'histone-mimetic'gold nanoparticles. Nanomedicine 7, 1657-1666. doi: 10.2217/nnm.12.21

Conner, S. D., and Schmid, S. L. (2003). Regulated portals of entry into the cell. Nature 422, 37-44. doi: 10.1038/nature01451

Conroy, J., Byrne, S. J., Gun'ko, Y. K., Rakovich, Y. P., Donegan, J. F., Davies, A., et al. (2008). CdTe nanoparticles display tropism to core histones and histone-rich cell organelles. Small 4, 2006-2015. doi: 10.1002/smll.200800088

Damm, E.-M., Pelkmans, L., Kartenbeck, J., Mezzacasa, A., Kurzchalia, T., and Helenius, A. (2005). Clathrin-and caveolin-1-independent endocytosis: entry of simian virus 40 into cells devoid of caveolae. J. Cell Biol. 168, 477-488. doi: $10.1083 /$ jcb. 200407113

Dausend, J., Musyanovych, A., Dass, M., Walther, P., Schrezenmeier, H., Landfester, K., et al. (2008). Uptake mechanism of oppositely charged fluorescent nanoparticles in HeLa cells. Macromol. Biosci. 8, 1135-1143. doi: $10.1002 / \mathrm{mabi} .200800123$

Deponte, M. (2013). Glutathione catalysis and the reaction mechanisms of glutathione-dependent enzymes. Biochim. Biophys. Acta 1830, 3217-3266. doi: 10.1016/j.bbagen.2012.09.018

Doherty, G. J., and McMahon, H. T. (2009). Mechanisms of endocytosis. Annu. Rev. Biochem. 78, 857-902. doi: 10.1146/annurev.biochem.78.081307.110540

Dong, X., and Weng, Z. (2013). The correlation between histone modifications and gene expression. Epigenomics 5, 113-116. doi: 10.2217/epi.13.13

Dusinska, M., Tulinska, J., El Yamani, N., Kuricova, M., Liskova, A., Rollerova, E., et al. (2017). Immunotoxicity, genotoxicity and epigenetic toxicity of 
nanomaterials: new strategies for toxicity testing? Food Chem. Toxicol. 109, 797-811. doi: 10.1016/j.fct.2017.08.030

Eom, H.-J., Chatterjee, N., Lee, J., and Choi, J. (2014). Integrated mRNA and micro RNA profiling reveals epigenetic mechanism of differential sensitivity of Jurkat $\mathrm{T}$ cells to AgNPs and Ag ions. Toxicol. Lett. 229, 311-318. doi: 10.1016/j.toxlet.2014.05.019

Esteller, M. (2008). Epigenetics in cancer. N. Eng. J. Med. 358, 1148-1159. doi: 10.1056/NEJMra072067

Ferguson, J. P., Huber, S. D., Willy, N. M., Aygün, E., Goker, S., Atabey, T., et al. (2017). Mechanoregulation of clathrin-mediated endocytosis. J. Cell Sci. 130, 3631-3636. doi: $10.1242 /$ jcs. 205930

Ferreira, A. P., and Boucrot, E. (2018). Mechanisms of carrier formation during clathrin-independent endocytosis. Trends Cell Biol. 28, 188-200. doi: $10.1016 /$ j.tcb.2017.11.004

Foroozandeh, P., and Aziz, A. A. (2018). Insight into cellular uptake and intracellular trafficking of nanoparticles. Nanoscale Res. Lett. 13:339. doi: 10.1186/s11671-018-2728-6

Frías-Lasserre, D., and Villagra, C. A. (2017). The importance of ncRNAs as epigenetic mechanisms in phenotypic variation and organic evolution. Front. Microbiol. 8:2483. doi: 10.3389/fmicb.2017.02483

Gao, F., Ma, N., Zhou, H., Wang, Q., Zhang, H., Wang, P., et al. (2016). Zinc oxide nanoparticles-induced epigenetic change and G2/M arrest are associated with apoptosis in human epidermal keratinocytes. Int. J. Nanomed. 11, 3859-3874. doi: 10.2147/IJN.S107021

Geiser, M., Rothen-Rutishauser, B., Kapp, N., Schürch, S., Kreyling, W., Schulz, H., et al. (2005). Ultrafine particles cross cellular membranes by nonphagocytic mechanisms in lungs and in cultured cells. Environ. Health Perspect. 113, 1555-1560. doi: 10.1289/ehp.8006

Ghosh, M., Öner, D., Duca, R. C., Bekaert, B., Vanoirbeek, J. A., Godderis, L., et al. (2018). Single-walled and multi-walled carbon nanotubes induce sequencespecific epigenetic alterations in 16 HBE cells. Oncotarget 9, 20351-20365. doi: 10.18632/oncotarget.24866

Ghosh, M., Öner, D., Poels, K., Tabish, A. M., Vlaanderen, J., Pronk, A., et al. (2017). Changes in DNA methylation induced by multi-walled carbon nanotube exposure in the workplace. Nanotoxicology 11, 1195-1210. doi: 10.1080/17435390.2017.1406169

Ghosh, M., Öner, D., Tabish, A., Poels, K., Hoet, P., Pronk, A., et al. (2016). DNA methylation changes in workers occupational exposed to carbon nanotubes. Eur. Respir. J. 48:PA4275. doi: 10.1183/13993003.congress-2016.PA4275

Gong, C., Tao, G., Yang, L., Liu, J., Liu, Q., Li, W., et al. (2012). Methylation of PARP-1 promoter involved in the regulation of nano-SiO2induced decrease of PARP-1 mRNA expression. Toxicol. Lett. 209, 264-269. doi: 10.1016/j.toxlet.2012.01.007

Gong, C., Tao, G., Yang, L., Liu, J., Liu, Q., and Zhuang, Z. (2010). SiO2 nanoparticles induce global genomic hypomethylation in $\mathrm{HaCaT}$ cells. Biochem. Biophys. Res. Commun. 397, 397-400. doi: 10.1016/j.bbrc.2010.05.076

Gratton, S. E., Ropp, P. A., Pohlhaus, P. D., Luft, J. C., Madden, V. J., Napier, M. E., et al. (2008). The effect of particle design on cellular internalization pathways. Proc. Natl. Acad. Sci. U.S.A. 105, 11613-11618. doi: 10.1073/pnas.0801763105

Gurunathan, S., Qasim, M., Park, C., Yoo, H., Choi, D., Song, H., et al. (2018). Cytotoxicity and transcriptomic analysis of silver nanoparticles in mouse embryonic fibroblast cells. Int. J. Mol. Sci. 19:E3618. doi: 10.3390/ijms19113618

Ha, S.-W., Jang, H. L., Nam, K. T., and Beck G. R. Jr. (2015). Nanohydroxyapatite modulates osteoblast lineage commitment by stimulation of DNA methylation and regulation of gene expression. Biomaterials 65, 32-42. doi: 10.1016/j.biomaterials.2015.06.039

Halappanavar, S., Jackson, P., Williams, A., Jensen, K. A., Hougaard, K. S., Vogel, U., et al. (2011). Pulmonary response to surface-coated nanotitanium dioxide particles includes induction of acute phase response genes, inflammatory cascades, and changes in microRNAs: a toxicogenomic study. Environ. Mol. Mutagen. 52, 425-439. doi: 10.1002/em.20639

Hassinger, J. E., Oster, G., Drubin, D. G., and Rangamani, P. (2017). Design principles for robust vesiculation in clathrin-mediated endocytosis. Proc. Natl. Acad. Sci. U.S.A. 114, E1118-E1127. doi: 10.1073/pnas.16177 05114

Hauck, T. S., Ghazani, A. A., and Chan, W. C. (2008). Assessing the effect of surface chemistry on gold nanorod uptake, toxicity, and gene expression in mammalian cells. Small 4, 153-159. doi: 10.1002/smll.200700217
Hendrich, B., and Bird, A. (1998). Identification and characterization of a family of mammalian methyl CpG-binding proteins. Genet. Res. 72, 59-72. doi: 10.1017/S0016672398533307

Herd, H., Daum, N., Jones, A. T., Huwer, H., Ghandehari, H., and Lehr, C.M. (2013). Nanoparticle geometry and surface orientation influence mode of cellular uptake. ACS Nano 7, 1961-1973. doi: 10.1021/nn304439f

Hillaireau, H., and Couvreur, P. (2009). Nanocarriers' entry into the cell: relevance to drug delivery. Cell. Mol Life Sci. 66, 2873-2896. doi: 10.1007/s00018-009-0053-z

Ho, D., Kretzmann, J. A., Norret, M., Toshniwal, P., Veder, J.-P., Jiang, H., et al. (2018). Intracellular speciation of gold nanorods alters the conformational dynamics of genomic DNA. Nat. Nanotechnol. 13, 1148-1153. doi: 10.1038/s41565-018-0272-2

Holzapfel, V., Lorenz, M., Weiss, C. K., Schrezenmeier, H., Landfester, K., and Mailänder, V. (2006). Synthesis and biomedical applications of functionalized fluorescent and magnetic dual reporter nanoparticles as obtained in the miniemulsion process. J. Phys. Condens. Matter 18:S2581. doi: 10.1088/0953-8984/18/38/S04

Hu, J., Lin, W., Lin, B., Wu, K., Fan, H., and Yu, Y. (2019). Persistent DNA methylation changes in zebrafish following graphene quantum dots exposure in surface chemistry-dependent manner. Ecotoxicol. Environ. Saf. 169, 370-375. doi: 10.1016/j.ecoenv.2018.11.053

Ishii, Y., Hattori, Y., Yamada, T., Uesato, S., Maitani, Y., and Nagaoka, Y. (2009). Histone deacetylase inhibitor prodrugs in nanoparticle vector enhanced gene expression in human cancer cells. Eur. J. Med. Chem. 44, 4603-4610. doi: 10.1016/j.ejmech.2009.06.036

Jain, A., Singh, D., Dubey, K., Maurya, R., and Pandey, A. (2019). Zinc oxide nanoparticles induced gene mutation at the HGPRT locus and cell cycle arrest associated with apoptosis in V-79 cells. J. Appl. Toxicol. 39, 735-750. doi: 10.1002/jat.3763

Jin, H., Heller, D. A., Sharma, R., and Strano, M. S. (2009). Size-dependent cellular uptake and expulsion of single-walled carbon nanotubes: single particle tracking and a generic uptake model for nanoparticles. ACS Nano 3, 149-158. doi: 10.1021/nn800532m

Kim, D. H., Villeneuve, L. M., Morris, K. V., and Rossi, J. J. (2006). Argonaute1 directs siRNA-mediated transcriptional gene silencing in human cells. Nat. Struct. Mol. Biol. 13, 793-797. doi: 10.1038/nsmb1142

Kirkham, M., Fujita, A., Chadda, R., Nixon, S. J., Kurzchalia, T. V., Sharma, D. K., et al. (2005). Ultrastructural identification of uncoated caveolin-independent early endocytic vehicles. J. Cell Biol. 168, 465-476. doi: 10.1083/jcb.200407078

Kovvuru, P., Mancilla, P. E., Shirode, A. B., Murray, T. M., Begley, T. J., and Reliene, R. (2015). Oral ingestion of silver nanoparticles induces genomic instability and DNA damage in multiple tissues. Nanotoxicology 9, 162-171. doi: 10.3109/17435390.2014.902520

Kuhn, D. A., Vanhecke, D., Michen, B., Blank, F., Gehr, P., Petri-Fink, A., et al. (2014). Different endocytotic uptake mechanisms for nanoparticles in epithelial cells and macrophages. Beilstein J. Nanotechnol. 5, 1625-1636. doi: 10.3762/bjnano.5.174

Lee, H.-Y., Shin, S. H. R., Abezgauz, L. L., Lewis, S. A., Chirsan, A. M., Danino, D. D., et al. (2013). Integration of gold nanoparticles into bilayer structures via adaptive surface chemistry. J. Am. Chem. Soc. 135, 5950-5953. doi: $10.1021 /$ ja400225n

Li, J., Tian, M., Cui, L., Dwyer, J., Fullwood, N. J., Shen, H., et al. (2016). Lowdose carbon-based nanoparticle-induced effects in A549 lung cells determined by biospectroscopy are associated with increases in genomic methylation. Sci. Rep. 6:20207. doi: 10.1038/srep20207

Li, S., Wang, H., Qi, Y., Tu, J., Bai, Y., Tian, T., et al. (2011a). Assessment of nanomaterial cytotoxicity with SOLiD sequencing-based microRNA expression profiling. Biomaterials 32, 9021-9030. doi: 10.1016/j.biomaterials.2011.08.033

Li, S., Wang, Y., Wang, H., Bai, Y., Liang, G., Wang, Y., et al. (2011b). MicroRNAs as participants in cytotoxicity of CdTe quantum dots in NIH/3T3 cells. Biomaterials 32, 3807-3814. doi: 10.1016/j.biomaterials.2011.01.074

Lim, J. P., and Gleeson, P. A. (2011). Macropinocytosis: an endocytic pathway for internalising large gulps. Immunol. Cell Biol. 89, 836-843. doi: $10.1038 /$ icb. 2011.20

Liu, R., Jiang, W., Walkey, C. D., Chan, W. C., and Cohen, Y. (2015). Prediction of nanoparticles-cell association based on corona proteins and physicochemical properties. Nanoscale 7, 9664-9675. doi: 10.1039/C5NR01537E 
Lovrić, J., Bazzi, H. S., Cuie, Y., Fortin, G. R., Winnik, F. M., and Maysinger, D. (2005). Differences in subcellular distribution and toxicity of green and red emitting CdTe quantum dots. J. Mol. Med. 83, 377-385. doi: 10.1007/s00109-004-0629-x

Lu, F., Wu, S. H., Hung, Y., and Mou, C. Y. (2009). Size effect on cell uptake in well-suspended, uniform mesoporous silica nanoparticles. Small 5, 1408-1413. doi: 10.1002/smll.200900005

Lu, L., Guo, L., Wang, X., Kang, T., and Cheng, S. (2016). Complexation and intercalation modes: a novel interaction of DNA and graphene quantum dots. RSC Adv. 6, 33072-33075. doi: 10.1039/C6RA00930A

Lu, R., Drubin, D. G., and Sun, Y. (2016). Clathrin-mediated endocytosis in budding yeast at a glance. J. Cell Sci. 129, 1531-1536. doi: 10.1242/jcs.182303

Lu, X., Miousse, I. R., Pirela, S. V., Melnyk, S., Koturbash, I., and Demokritou, P. (2016a). Short-term exposure to engineered nanomaterials affects cellular epigenome. Nanotoxicology 10, 140-150. doi: 10.3109/17435390.2015.1025115

Lu, X., Miousse, I. R., Pirela, S. V., Moore, J. K., Melnyk, S., Koturbash, I., et al. (2016b). In vivo epigenetic effects induced by engineered nanomaterials: a case study of copper oxide and laser printer-emitted engineered nanoparticles. Nanotoxicology 10, 629-639. doi: 10.3109/17435390.2015.1108473

Ma, Y., Fu, H., Zhang, C., Cheng, S., Gao, J., Wang, Z., et al. (2016). Chiral antioxidant-based gold nanoclusters reprogram DNA epigenetic patterns. Sci. Rep. 6:33436. doi: 10.1038/srep33436

Ma, Y., Guo, Y., Wu, S., Lv, Z., Zhang, Q., and Ke, Y. (2017). Titanium dioxide nanoparticles induce size-dependent cytotoxicity and genomic DNA hypomethylation in human respiratory cells. RSC $A d v .7,23560-23572$. doi: 10.1039/C6RA28272E

Mahmood, M., Li, Z., Casciano, D., Khodakovskaya, M. V., Chen, T., Karmakar, A., et al. (2011). Nanostructural materials increase mineralization in bone cells and affect gene expression through miRNA regulation. J. Cell. Mol. Med. 15, 2297-2306. doi: 10.1111/j.1582-4934.2010.01234.x

Malumbres, M. (2014). Cyclin-dependent kinases. Genome Biol. 15:122. doi: $10.1186 / \mathrm{gb} 4184$

Marano, F., Hussain, S., Rodrigues-Lima, F., Baeza-Squiban, A., and Boland, S. (2011). Nanoparticles: molecular targets and cell signalling. Arch. Toxicol. 85, 733-741. doi: 10.1007/s00204-010-0546-4

Mazumder, A., and Shivashankar, G. (2007). Gold-nanoparticle-assisted laser perturbation of chromatin assembly reveals unusual aspects of nuclear architecture within living cells. Biophys. J. 93, 2209-2216. doi: 10.1529/biophysj.106.102202

Mellman, I., and Nelson, W. J. (2008). Coordinated protein sorting, targeting and distribution in polarized cells. Nat. Rev. Mol. Cell Biol. 9, 833-845. doi: $10.1038 / \mathrm{nrm} 2525$

Mytych, J., Zebrowski, J., Lewinska, A., and Wnuk, M. (2017). Prolonged effects of silver nanoparticles on $\mathrm{p} 53 / \mathrm{p} 21$ pathway-mediated proliferation, DNA damage response, and methylation parameters in HT22 hippocampal neuronal cells. Mol. Neurobiol. 54, 1285-1300. doi: 10.1007/s12035-016-9688-6

Nagano, T., and Fraser, P. (2009). Emerging similarities in epigenetic gene silencing by long noncoding RNAs. Mammal. Genome 20, 557-562. doi: $10.1007 / \mathrm{s} 00335-009-9218-1$

Nagano, T., Higashisaka, K., Kunieda, A., Iwahara, Y., Tanaka, K., Nagano, K., et al. (2013). Liver-specific microRNAs as biomarkers of nanomaterial-induced liver damage. Nanotechnology 24:405102. doi: 10.1088/0957-4484/24/40/405102

Nallanthighal, S., Chan, C., Murray, T. M., Mosier, A. P., Cady, N. C., and Reliene, R. (2017). Differential effects of silver nanoparticles on DNA damage and DNA repair gene expression in Ogg1-deficient and wild type mice. Nanotoxicology 11, 996-1011. doi: 10.1080/17435390.2017.1388863

Nash, J. A., Singh, A., Li, N. K., and Yingling, Y. G. (2015). Characterization of nucleic acid compaction with histone-mimic nanoparticles through all-atom molecular dynamics. ACS Nano 9, 12374-12382. doi: 10.1021/acsnano.5b05684

Ng, C.-T., Dheen, S. T., Yip, W.-C. G., Ong, C.-N., Bay, B.-H., and Yung, L.Y. L. (2011). The induction of epigenetic regulation of PROS1 gene in lung fibroblasts by gold nanoparticles and implications for potential lung injury. Biomaterials 32, 7609-7615. doi: 10.1016/j.biomaterials.2011.06.038

Oberdörster, G., Oberdörster, E., and Oberdörster, J. (2005). Nanotoxicology: an emerging discipline evolving from studies of ultrafine particles. Environ. Health Perspect. 113, 823-839. doi: 10.1289/ehp.7339

Ognik, K., Cholewinska, E., Juśkiewicz, J., Zdunczyk, Z., Tutaj, K., and Szlazak, R. (2019). The effect of copper nanoparticles and copper (II) salt on redox reactions and epigenetic changes in a rat model. J. Anim. Physiol. Anim. Nutr. 103, 675-686. doi: 10.1111/jpn.13025

Ohnishi, Y., Totoki, Y., Toyoda, A., Watanabe, T., Yamamoto, Y., Tokunaga, K., et al. (2010). Small RNA class transition from siRNA/piRNA to miRNA during pre-implantation mouse development. Nucleic Acids Res. 38, 5141-5151. doi: 10.1093/nar/gkq229

Oksel, C., Ma, C. Y., and Wang, X. Z. (2015). Structure-activity relationship models for hazard assessment and risk management of engineered nanomaterials. Proc. Eng. 102, 1500-1510. doi: 10.1016/j.proeng.2015. 01.284

Olubummo, A., Schulz, M., Lechner, B.-D., Scholtysek, P., Bacia, K., Blume, A., et al. (2012). Controlling the localization of polymer-functionalized nanoparticles in mixed lipid/polymer membranes. ACS Nano 6, 8713-8727. doi: $10.1021 / \mathrm{nn} 3023602$

Öner, D., Moisse, M., Ghosh, M., Duca, R. C., Poels, K., Luyts, K., et al. (2016). Epigenetic effects of carbon nanotubes in human monocytic cells. Mutagenesis 32, 181-191. doi: 10.1093/mutage/gew053

Osaki, F., Kanamori, T., Sando, S., Sera, T., and Aoyama, Y. (2004). A quantum dot conjugated sugar ball and its cellular uptake. On the size effects of endocytosis in the subviral region. J. Am. Chem. Soc. 126, 6520-6521. doi: $10.1021 / \mathrm{ja} 048792 \mathrm{a}$

Panariti, A., Miserocchi, G., and Rivolta, I. (2012). The effect of nanoparticle uptake on cellular behavior: disrupting or enabling functions? Nanotechnol. Sci. Appl. 5, 87-100. doi: 10.2147/NSA.S25515

Parton, R. G., and Simons, K. (2007). The multiple faces of caveolae. Nat. Rev. Mol. Cell Biol. 8, 185-194. doi: 10.1038/nrm2122

Patil, N. A., Gade, W., and Deobagkar, D. D. (2016). Epigenetic modulation upon exposure of lung fibroblasts to $\mathrm{TiO} 2$ and $\mathrm{ZnO}$ nanoparticles: alterations in DNA methylation. Int. J. Nanomed. 11, 4509-4519. doi: 10.2147/IJN.S1 10390

Paul, P., Chakraborty, A., Sarkar, D., Langthasa, M., Rahman, M., Bari, M., et al. (2018). Interplay between miRNAs and human diseases. J. Cell. Physiol. 233, 2007-2018. doi: 10.1002/jcp.25854

Pauwels, A.-M., Trost, M., Beyaert, R., and Hoffmann, E. (2017). Patterns, receptors, and signals: regulation of phagosome maturation. Trends Immunol. 38, 407-422. doi: 10.1016/j.it.2017.03.006

Peschansky, V. J., and Wahlestedt, C. (2014). Non-coding RNAs as direct and indirect modulators of epigenetic regulation. Epigenetics 9, 3-12. doi: 10.4161/epi.27473

Portela, A., and Esteller, M. (2010). Epigenetic modifications and human disease. Nat. Biotechnol. 28, 1057-1068. doi: 10.1038/nbt.1685

Qian, Y., Zhang, J., Hu, Q., Xu, M., Chen, Y., Hu, G., et al. (2015). Silver nanoparticle-induced hemoglobin decrease involves alteration of histone 3 methylation status. Biomaterials 70, 12-22. doi: 10.1016/j.biomaterials.2015.08.015

Qiu, Y., Liu, Y., Wang, L., Xu, L., Bai, R., Ji, Y., et al. (2010). Surface chemistry and aspect ratio mediated cellular uptake of Au nanorods. Biomaterials 31, 7606-7619. doi: 10.1016/j.biomaterials.2010.06.051

Rafiei, S., Dadmehr, M., Hosseini, M., Kermani, H. A., and Ganjali, M. R. (2019). A fluorometric study on the effect of DNA methylation on DNA interaction with graphene quantum dots. Methods Appl. Fluoresc. 7:025001. doi: 10.1088/2050-6120/aaff95

Robertson, K. D. (2005). DNA methylation and human disease. Nat. Rev. Genet. 6, 597-610. doi: 10.1038/nrg1655

Sandvig, K., Pust, S., Skotland, T., and van Deurs, B. (2011). Clathrin-independent endocytosis: mechanisms and function. Curr. Opin. Cell Biol. 23, 413-420. doi: 10.1016/j.ceb.2011.03.007

Singh, R., and Singh, S. (2019). "Nanomanipulation of consumer goods: effects on human health and environment," in Nanotechnology in Modern Animal Biotechnology, eds S. Singh and P. K. Maurya (Springer Nature), 221-254.

Smolkova, B., Dusinska, M., and Gabelova, A. (2017). Nanomedicine and epigenome. Possible health risks. Food Chem. Toxicol. 109, 780-796. doi: 10.1016/j.fct.2017.07.020

Smolkova, B., Dusinska, M., and Gabelova, A. (2018). "Epigenetic Effects of Nanomaterials," in Encyclopedia of Environmental Health, 2nd edn, ed J. Nriagu (Amsterdam: Elsevier), 1-8.

Soldati, T., and Schliwa, M. (2006). Powering membrane traffic in endocytosis and recycling. Nat. Rev. Mol. Cell Biol. 7, 897-908. doi: 10.1038/nrm2060 
Stoccoro, A., Karlsson, H. L., Coppedè, F., and Migliore, L. (2013). Epigenetic effects of nano-sized materials. Toxicology 313, 3-14. doi: $10.1016 /$ j.tox.2012.12.002

Strahl, B. D., and Allis, C. D. (2000). The language of covalent histone modifications. Nature 403, 41-45. doi: 10.1038/47412

Sule, N., Singh, R., and Srivastava, D. (2008). Alternative modes of binding of recombinant human histone deacetylase 8 to colloidal gold nanoparticles. J. Biomed. Nanotechnol. 4, 463-468. doi: 10.1166/jbn.2008.011

Sun, B., Liu, R., Ye, N., and Xiao, Z.-D. (2015). Comprehensive evaluation of microRNA expression profiling reveals the neural signaling specific cytotoxicity of superparamagnetic iron oxide nanoparticles (SPIONs) through N-methyl-D-aspartate receptor. PLoS ONE 10:e121671. doi: 10.1371/journal.pone.0121671

Sun, B., Yang, F., Hu, F.-H., Huang, N.-P., and Xiao, Z.-D. (2013). Comprehensive annotation of microRNA expression profiles. BMC Genet. 14:120. doi: 10.1186/1471-2156-14-120

Surapaneni, S. K., Bashir, S., and Tikoo, K. (2018). Gold nanoparticlesinduced cytotoxicity in triple negative breast cancer involves different epigenetic alterations depending upon the surface charge. Sci. Rep. 8:12295. doi: 10.1038/s41598-018-30541-3

Tabish, A. M., Poels, K., Byun, H.-M., Baccarelli, A. A., Martens, J., Kerkhofs, S., et al. (2017). Changes in DNA methylation in mouse lungs after a single intra-tracheal administration of nanomaterials. PLoS ONE 12:e169886. doi: 10.1371/journal.pone.0169886

Tenzer, S., Docter, D., Kuharev, J., Musyanovych, A., Fetz, V., Hecht, R., et al. (2013). Rapid formation of plasma protein corona critically affects nanoparticle pathophysiology. Nat. Nanotechnol. 8:772. doi: 10.1038/nnano.2013.181

Thorn, H., Stenkula, K. G., Karlsson, M., Ortegren, U., Nystrom, F. H., Gustavsson, J., et al. (2003). Cell surface orifices of caveolae and localization of caveolin to the necks of caveolae in adipocytes. Mol. Biol. Cell 14, 3967-3976. doi: 10.1091/mbc.e03-01-0050

Tucci, P., Porta, G., Agostini, M., Dinsdale, D., Iavicoli, I., Cain, K., et al. (2013). Metabolic effects of TiO 2 nanoparticles, a common component of sunscreens and cosmetics, on human keratinocytes. Cell Death Dis. 4:e549. doi: $10.1038 /$ cddis.2013.76

Vanlandingham, P. A., Barmchi, M. P., Royer, S., Green, R., Bao, H., Reist, N., et al. (2014). AP180 couples protein retrieval to clathrin-mediated endocytosis of synaptic vesicles. Traffic 15, 433-450. doi: 10.1111/tra.12153

Wang, B., Zhang, L., Bae, S. C., and Granick, S. (2008). Nanoparticleinduced surface reconstruction of phospholipid membranes. Proc. Natl. Acad. Sci. U.S.A. 105, 18171-18175. doi: 10.1073/pnas.08072 96105

Wang, S.-H., Lee, C.-W., Chiou, A., and Wei, P.-K. (2010). Size-dependent endocytosis of gold nanoparticles studied by three-dimensional mapping of plasmonic scattering images. J. Nanobiotechnol. 8:33. doi: $10.1186 / 1477-3155-8-33$

Wang, X., Sun, B., Liu, S., and Xia, T. (2017). Structure activity relationships of engineered nanomaterials in inducing NLRP3 inflammasome activation and chronic lung fibrosis. NanoImpact 6, 99-108. doi: 10.1016/j.impact.2016. 08.002
Wang, Z., Tiruppathi, C., Cho, J., Minshall, R. D., and Malik, A. B. (2011). Delivery of nanoparticle-complexed drugs across the vascular endothelial barrier via caveolae. IUBMB Life 63, 659-667. doi: 10.1002/iub.485

Xiang, S., Tong, H., Shi, Q., Fernandes, J. C., Jin, T., Dai, K., et al. (2012). Uptake mechanisms of non-viral gene delivery. J. Control. Release 158, 371-378. doi: 10.1016/j.jconrel.2011.09.093

Xu, L., Dai, Y., Wang, Z., Zhao, J., Li, F., White, J. C., et al. (2018). Graphene quantum dots in alveolar macrophage: uptake-exocytosis, accumulation in nuclei, nuclear responses and DNA cleavage. Part. Fibre Toxicol. 15:45. doi: 10.1186/s12989-018-0279-8

Yaari, Z., Da Silva, D., Zinger, A., Goldman, E., Kajal, A., Tshuva, R., et al. (2016). Theranostic barcoded nanoparticles for personalized cancer medicine. Nat. Commun. 7:13325. doi: 10.1038/ncomms13325

Zhang, F., Guo, H., Zhang, J., Chen, Q., and Fang, Q. (2018). Identification of the caveolae/raft-mediated endocytosis as the primary entry pathway for aquareovirus. Virology 513, 195-207. doi: 10.1016/j.virol.2017.09.019

Zhang, L., Han, B., Xiang, J., Liu, K., Dong, H., and Gao, X. (2018). Silica nanoparticle releases SIRT6-induced epigenetic silencing of follistatin. Int. J. Biochem. Cell Biol. 95, 27-34. doi: 10.1016/j.biocel.2017.12.011

Zhang, X.-F., Park, J.-H., Choi, Y.-J., Kang, M.-H., Gurunathan, S., and Kim, J.H. (2015). Silver nanoparticles cause complications in pregnant mice. Int. J. Nanomed. 10, 7057-7071. doi: 10.2147/IJN.S95694

Zhao, X., Rao, Y., Liang, J., Lin, S., Wang, X., Li, Z., et al. (2019). Silver nanoparticle-induced phosphorylation of histone $\mathrm{H} 3$ at serine 10 involves MAPK pathways. Biomolecules 9:78. doi: 10.3390/biom9020078

Zhao, X., Toyooka, T., and Ibuki, Y. (2017). Silver nanoparticle-induced phosphorylation of histone $\mathrm{H} 3$ at serine 10 is due to dynamic changes in actin filaments and the activation of Aurora kinases. Toxicol. Lett. 276, 39-47. doi: 10.1016/j.toxlet.2017.05.009

Zhou, T., Llizo, A., Wang, C., Xu, G., and Yang, Y. (2013). Nanostructure-induced DNA condensation. Nanoscale 5, 8288-8306. doi: 10.1039/c3nr01630g

Zhu, M., Nie, G., Meng, H., Xia, T., Nel, A., and Zhao, Y. (2012). Physicochemical properties determine nanomaterial cellular uptake, transport, and fate. Acc. Chem. Res. 46, 622-631. doi: 10.1021/ar300031y

Zou, Y., Li, Q., Jiang, L., Guo, C., Li, Y., Yu, Y., et al. (2016). DNA hypermethylation of CREB3L1 and Bcl-2 Associated with the mitochondrial-mediated apoptosis via PI3K/Akt pathway in human BEAS-2B cells exposure to silica nanoparticles. PLoS ONE 11:e0158475. doi: 10.1371/journal.pone.0158475

Conflict of Interest: The authors declare that the research was conducted in the absence of any commercial or financial relationships that could be construed as a potential conflict of interest.

Copyright (c) 2019 Gedda, Babele, Zahra and Madhukar. This is an open-access article distributed under the terms of the Creative Commons Attribution License (CC $B Y)$. The use, distribution or reproduction in other forums is permitted, provided the original author(s) and the copyright owner(s) are credited and that the original publication in this journal is cited, in accordance with accepted academic practice. No use, distribution or reproduction is permitted which does not comply with these terms. 